\title{
Comparison of Performance between Bi-facial and Mono- facial 10kW Photovoltaic Power Systems
}

\author{
H.D.Milan Ravinath Perera ${ }^{1}$ \\ Researcher (MSc,BEng(Hons),MIET,MIEEE) ${ }^{1}$ \\ ${ }^{1}$ Sustainable Energy Engineering \\ Mahara, Kadawatha
}

Sri Lanka

\begin{abstract}
This paper is based and written on performance analysis of a 10kW Grid-connected solar power system with a comparison in integration of bifacial photovoltaic systems vs mono-facial photovoltaic systems. Thus, all these tastings were carried out on computer simulations using PVSyst6 software \& MATLAB/Simulink. These simulations were done considering different albedos and tilt angles in order to identify power variations under different environmental conditions. The selected panels used monocrystalline type-high efficiency cells, both in bifacial and mono-facial and therefore, the technical parameters of both cell types will be the same in operating conditions. With the results obtained, it has shown the power gain in ground mounted-grid connected bifacial solar system is $23 \%$ more than the mono-facial solar power system and using these details, the researcher proposed a table that represents, most suitable PV panels for different site conditions.
\end{abstract}

Key Words: Mono-crystalline, Bifacial, Mono-Facial, Albedo, Tilt Angle, LCOE, Annual Energy Gain, Performance Ratio.

\section{INTRODUCTION}

The sustainable energy related developments are increasing in a significant way because we know the importance of the green energy concepts towards the future of the world. About $\$ 8$ trillion will be invested globally in renewable energy between $2016-$ 2040 and that is two third of investment in all power generation capacity [1]. The solar power industry is strongly spreading around the continents to harness the energy of the sun's irradiation to generate power with many research and developments, and there are four different photovoltaic technologies currently widely used in the industry, those are, Mono-crystalline PV, Polycrystalline PV, Thin-film and Bifacial PV[2]. These technologies are widely used in different ends in the industry such as ground mounted on-grid/off-grid large scale solar power systems, roof mounted solar power systems, building added photovoltaic (BAPV), building integrated photovoltaic systems (BIPV) and hybrid applications[3]. This paper is using a 10kW stand alone, ground mounted, grid connected solar power system for the analysis and simulations to bring forward the importance of integrating Bifacial solar panels in the given type application. Even though there are many topics related to the solar power systems such as MPPT, DMPPT, partial shading and etc., this paper is targeting to create an initial step towards the designing of solar power project and to expose an idea to the industry so it is more important at the initial stage of project designing, and financial modeling with estimation of return on investment. Selecting the correct solar panel according to the location is important as it will reflect the benefits throughout the project life cycle.

\section{LITERATURE REVIEW}

The $90 \%$ of worldwide used high efficiency solar panel cell type is Mono-crystalline silicon and it has the highest energy conversion rate of $25 \%$ maximum under standard test conditions (STC) when other poly-crystalline silicon cells have reached only 15-18\% under STC. Pseudo-square wafer is cut to produce Mono-crystalline solar cells under the manufacturing process and this sell type is expensive compared to all other cell types available in the market since its high efficiency and time consumption and energy consumption in manufacturing process [4]. 


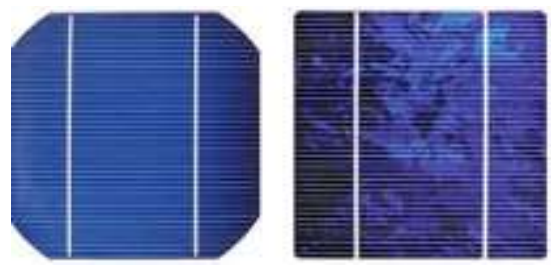

Fig 1. (Left) Mono crystalline and (Right) Polycrystalline cells [5]

These mono-crystalline solar cells will be connecting in series to create a complete solar panel which will be using for solar power generation as shown in standard equivalent circuit of solar cell connection figure 2.

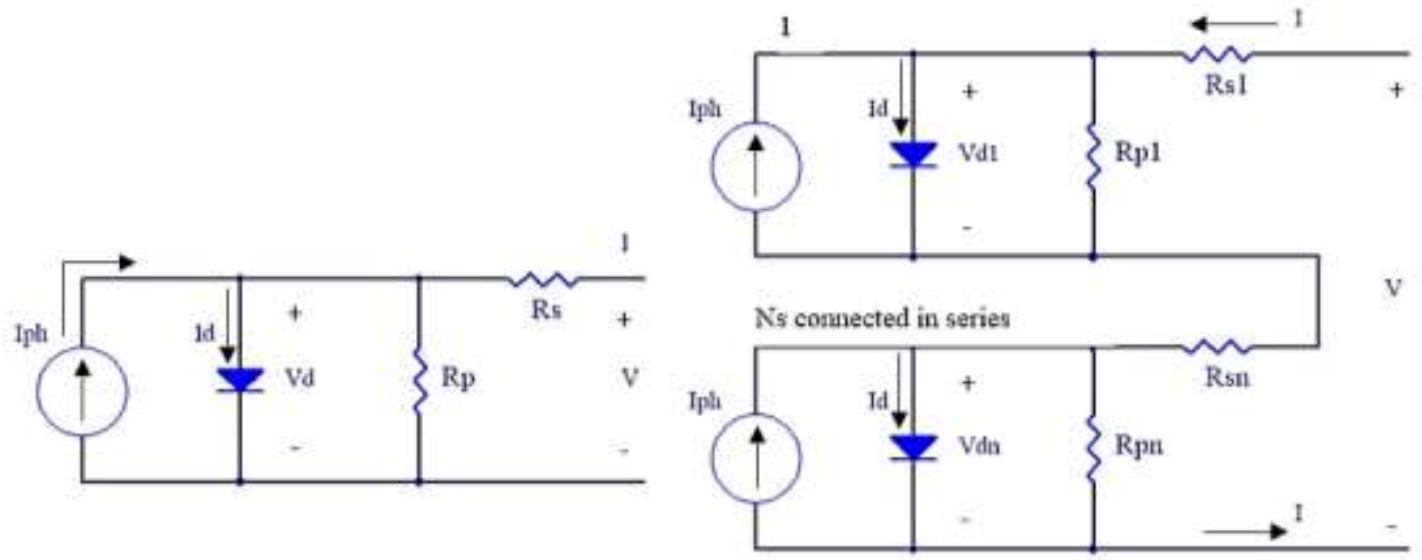

Fig 2. Equivalent circuit of $\mathbf{N}$ Series-connected PV cells [6]

According to the equivalent circuit, the equation for single sell can be written as follows,

$$
I=I_{p h}-I_{0}\left[\exp \left(\frac{V+I R_{S}}{A . N s . V_{T}}\right)-1\right]-\frac{V+I R_{S}}{R_{p}}
$$

$\mathrm{I}_{\mathrm{D}}$ is based on Shockley equation for an ideal diode, $\mathrm{I}$ is maximum generated current from the PV cell, $\mathrm{I}_{\mathrm{ph}}$ is light dependent current, $\mathrm{I}_{0}$ is diode reverse saturation current, $\mathrm{R}_{\mathrm{S}}$ is Series resistance, $\mathrm{R}_{\mathrm{P}}$ is shunt resistance, $A$ is the diode ideality factor that depend on recombination factor and $\mathrm{V}_{\mathrm{T}}$ is thermal voltage $(25.9 \mathrm{mV}$ at $300 \mathrm{~K})$. With Ns number of cells connect in series, the equation can be rewrite as,

$$
\begin{gathered}
I_{M}=I_{L}-I_{0}\left[\exp \left(\frac{V+I_{M} N R_{S}}{\eta N s V_{T}}\right)-1\right]-\frac{V+I_{M} N s R_{S}}{N s R_{p}} \\
V_{T}=K \cdot T_{C} / q
\end{gathered}
$$

$\mathrm{K}$ is Boltzmann constant of $1.381 \times 10^{-23} \mathrm{~J} / \mathrm{K}$, and ' $\mathrm{q}$ ' is electron charge of $1.602 \times 10-19 \mathrm{C}$. All the terms for $\mathrm{V}$ divided in equation under exponential function will inversely proportional to cell temperature and vary with conditions such as irradiation and temperature. Therefore, it can be re-write as " $\mathrm{a}$ " and thermal voltage where ' $\mathrm{a}$ ' is modified ideality factor.

$$
a=\frac{N s \cdot A \cdot K \cdot T c}{q}=N s \cdot A \cdot V_{T}
$$

Therefore, the output current of a module containing Ns cells in series will be denote as,

$$
I=I_{p h}-I_{o}\left[\exp \left(\frac{V+I \cdot R s}{a}\right)-1\right]-\frac{V+R s . I}{R p}
$$

Iph depend on both irradiance and temperature, therefore,

$$
I_{p h}=\frac{G}{G_{r e f}}\left(I_{p h, r e f}+\mu_{s c} . \Delta T\right)
$$

$\mathrm{G}$ and Gref will be irradiance and irradiance at STC $(1000 \mathrm{~W} / \mathrm{m} 2)$ respectively. $\mu_{s c}$ is known as coefficient temperature of short circuit current $(\mathrm{A} / \mathrm{K})$ and $\Delta T=\mathrm{Tc}$-Tc,ref (Kelvin) where Tc,ref is the cell temperature at STC $(25+273 \mathrm{~K})$. To determine Io, 
following relationships should be considered, Current at short circuit (V=0, I=Isc,ref), voltage (Vmp,ref), current (Imp,ref) at maximum Power. Therefore, it can obtain[7],

$$
\begin{gathered}
I_{s c, r e f}=I_{p h, r e f}-I_{0, r e f}\left[\exp \left(\frac{I_{s c, r e f \cdot R s}}{a_{\text {ref }}}\right)-1\right] \\
0=I_{p h, r e f}-I_{0, r e f}\left[\exp \left(\frac{V o c}{a_{r e f}}\right)-1\right] \\
I_{p m, r e f}=I_{p h, r e f}-I_{0, r e f}\left[\exp \left(\frac{V p m, r e f+I p m, r e f . R s}{a_{r e f}}\right)-1\right]
\end{gathered}
$$

Thus,

$$
\begin{gathered}
I_{0, r e f}=I_{s c, r e f} \cdot \exp \left(\frac{-V o c, r e f}{a}\right) \\
I o=D T c^{3} \exp \left(\frac{-q \varepsilon G}{A \cdot K}\right)
\end{gathered}
$$

Where, Io is the revers saturation current[8]. With relevant to the manufacturing phenomenon the panels will be divided into two categories which is mono-facial photovoltaic panels and bi-facial photovoltaic panels. Mono-facial PV has the glass lamination in front side while the rear is covered with opaque[9]. The solar irradiation containing photons will be absorbed by the silicon wafer and refer to a chemical reaction it produces electrons which will be creating a current flow. To capture more photons from sun for longer period of time to produce electrons, the mono-facial solar panel has a metallic back sheet which is commonly made with aluminum because of its $90 \%$ reflection rate[10]. The layout of typical mono-facial solar panel is shown in figure 3 .

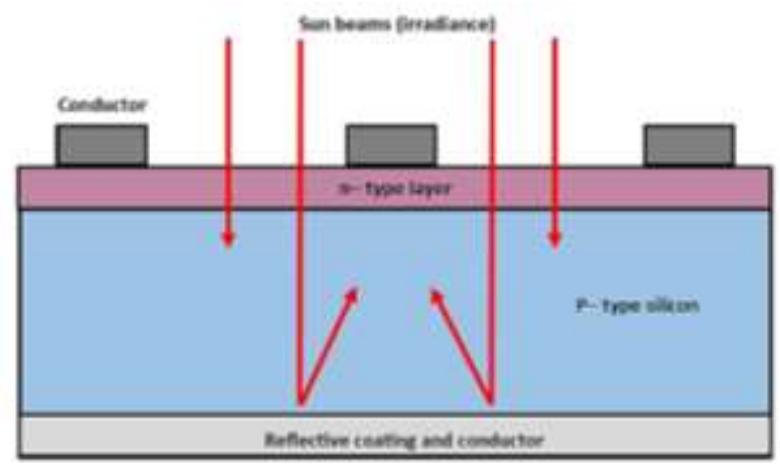

Fig 3. Mono-facial solar panel structure

The structure of bi-facial solar panel is different from the mono-facial solar panel. It has the ability to produce electrons by absorbing the photons from the rear side of the panel while performing front side as similar to the mono-facial solar panel [10]. This effect will increase the generation compared to conventional solar panel PERC or PERL[11]. The bi-facial cell can be optimized into two methods in panel construction, which is glass to glass type and glass to back sheet type. Under STC conditions the glass/back sheet will produce more module current due to its back-sheet scattering effect while glass/glass will produce more energy under outdoor environment conditions [12]. The below figure 4 represents the bifacial structure of glass/glass type panel.

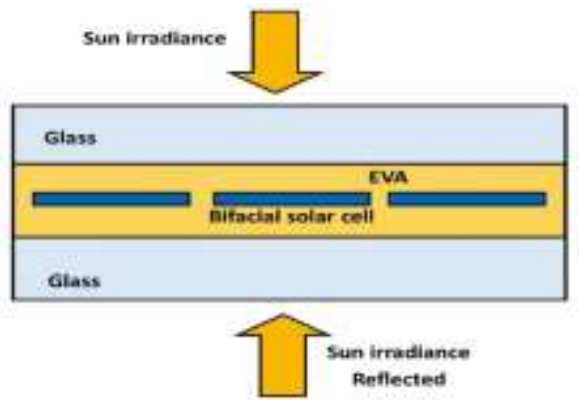

Fig 4. Bi-facial glass/glass type solar panel structure. 
Therefore, the rear side irradiance of a bi-facial panel will influence more on efficiency, and these energy gain will be influenced by design factors and environmental factors. The most important design factors associate with bifacial system are, panel elevation and albedo rate of under laying surface [13]. The ratio of energy increasing to panel height from ground level will be saturate at 0.4 0.5m, and more than $1 \mathrm{~m}$ is mostly preferable in ground mounted solar power station application[13]. The term Albedo is based on the ground-reflection and which the ground reflection irradiance will be affected on bifacial panel rear efficiency gain. This can be expressed as below formula[14],

$$
\text { Albedo of the surface }=\frac{\text { Reflected light }}{\text { Incident light }}
$$

There are two albedo irradiation criteria's and one is 'low albedo' and other is 'high albedo'. Low albedo is for 0.25 rates and it's output perform is similar to ground mounted bifacial solar system and the high albedo is from 0.5 [15]. To test the bifacial performance with albedo rate, DuRock Alfacing International Manufacturing Company used reflective white roof material named TIOCOAT below the panels and observed 7\% increment in bifacial panel wattage, and also in 1984 the experiment conducted in Madrid, Spain found that bifacial photovoltaic panels can collect 59\% more energy compared to conventional panels when mounting on a white painted floor[16]. Apart from these main two parameters, front and back electrical/optical parameters, module orientation, module to module distance, NS/EW facing, will be considered in designing the system. The environmental conditions such as, intensity of sunlight, direct and diffuse sunlight,[17] ambient temperature, wind speed, dust and latitude will be influence on the energy production in the system[18]. When sitting the bifacial solar panels, the most two common configurations will be optimal tilted South/North-facing and vertical East/West-facing, and if there are any obstructions in the field view, the annual energy will be decrease[19]. According to the past researches in different fields, the annual gain from bifacial ground mounted system will be $15 \sim 30 \%$ and $7-15 \%$ in roof-top mounted system, and as per the financial analysis of the bifacial power production, it has reduced the levelized cost of electricity (LCOE) because of high efficient, more production per unit area reduces the number of panels requirement which reduce the project cost[20]. There are several important equations related to bifacial solar panels, these equations can be defined as follows, the irradiance ratio (x) can be calculated by using,

$$
x=\frac{G_{r}}{G_{f}}
$$

Which, $G_{f}$ is irradiance on front side of panel and $G_{r}$ is irradiance on rear side of panel. The power $\left(P_{b i}\right)$ and efficiency ( $\left.n_{b i}\right)$ of bifacial modules can be defined as follows,

$$
\begin{gathered}
P_{b i}=I_{s c-b i} \cdot V_{o c-b i} \cdot F F_{b i} \\
\eta_{b i}=\frac{I_{s c-b i} \cdot V_{o c-b i} \cdot F F_{b i}}{A_{\text {module }} \cdot\left(G_{f}+G_{r}\right)}
\end{gathered}
$$

$\mathrm{I}_{\mathrm{sc}-\mathrm{bi}}$ - short circuit current, $\mathrm{V}_{\mathrm{oc}-\mathrm{bi}}$ - open circuit voltage, $\mathrm{FF}_{\mathrm{bi}}$ - Fill factor, $\mathrm{A}_{\text {module }}$ - surface area of front side of the panel. These parameters will be obtained under STC conditions which is, irradiance of $1000 \mathrm{~W} / \mathrm{m} 2$ and module temperature of $25^{\circ} \mathrm{C}$ [21]. In designing a PV power station, the main input data of irradiation in the given location will be taken from data bases which will be, National Solar Radiation Database (NSRDB)[22] and NASA surface meteorological and solar energy data base which has access for 40 years of solar meteorological data worldwide[23]. Also, Purdue University meteorological tool (PUMET) has come up with a new software of generating meteorological data files in any location and these details can be directly import into PV design software tools like PVSyst [17]. These obtained global irradiation at the specific location can be effect on bifacial panels rear side in four different ways, 1.Sky diffuse irradiance, 2.Ground reflected irradiance, 3.Structure reflected irradiance and 4.Direct irradiation on the back surface[24]. 


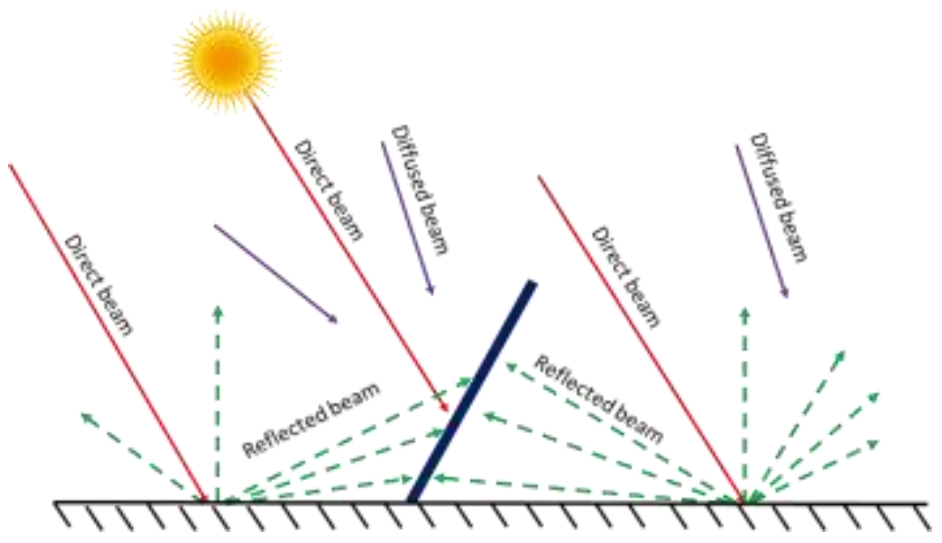

Fig 5. Direct, diffuse, reflected irradiance

Direct irradiance will be at which the sun irradiance will reach the surface of earth directly. Direct bean radiation $I_{B}$ has a relationship with collector surface $I_{B C}$ and incident angle $\theta$.

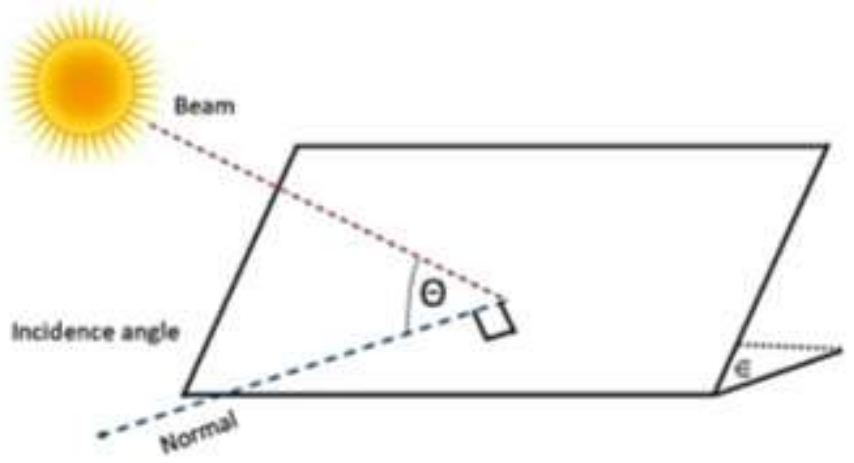

Fig 6. Irradiation on collector surface

Therefore the beam insolation on collector can be expressed as below equation[25],

$$
I_{B C}=I_{B} \cos \theta
$$

Even though, some beams will be diffuse by clouds and atmosphere and it is called the diffused irradiance. Calculating diffuse irradiance is more difficult since it is influenced by many environmental factors as described above. As per the model developed by Threlked and Jordan in 1958, the diffuse insolation on horizontal surface Idh is proportional to direct beam Ib. With this approximation the below relationship can be generated.

$$
I_{D H}=I_{B} \cdot C
$$

Where $\mathrm{C}$ is the sky diffuse factor, and it can be expressed as[26],

$$
C=0.095+0.04 \sin \left\{\frac{360}{365}(n-100)\right\}
$$

Thus, with the approximation of diffuse irradiance at site is equal in intensity from all directions, it is created the below equation of diffuse irradiance on collector with the use of horizontal diffuse irradiance $I_{D H}$, diffuse insolation $I_{B C}$ and tilt angle $\in$.

$$
I_{D C}=I_{D H}\left(\frac{1+\cos \epsilon}{2}\right)=I_{B C}\left(\frac{1+\cos \epsilon}{2}\right)
$$

The direct beams and diffused beams will be reflected by earth's surface as a percentage with refer to the albedo rate and this will be the reflected irradiance [27]. With the usage of global irradiation on horizontal surface $G_{T H}$ with tilt angle $\in$, the ground reflected radiation $G_{R C}$ can be calculated[28]. 


$$
G_{R C}=G_{T H} \cdot\left(\frac{1-\cos \epsilon}{2}\right)
$$

In every PV system, one of the key function is MPPT (Maximum Power Point Tracking). MPPT is widely used in every PV power application thus it is necessary to track the maximum power under different irradiation levels. This MPP is tracked by changing the duty cycle of the converter to control the output voltage. There are several types of MPPT methods designed and developed, while most commonly used are,

Perturb and Observed ( $\mathrm{P} \& \mathrm{O})$; This is also known as Hill climbing method as it depends on the rise of power curve against voltage. This controls and adjust the voltage in the direction of power increase. As soon as the power output starts decreasing, the perturbation will occur in the opposite direction. This method is simple to implement and cost effective[29].

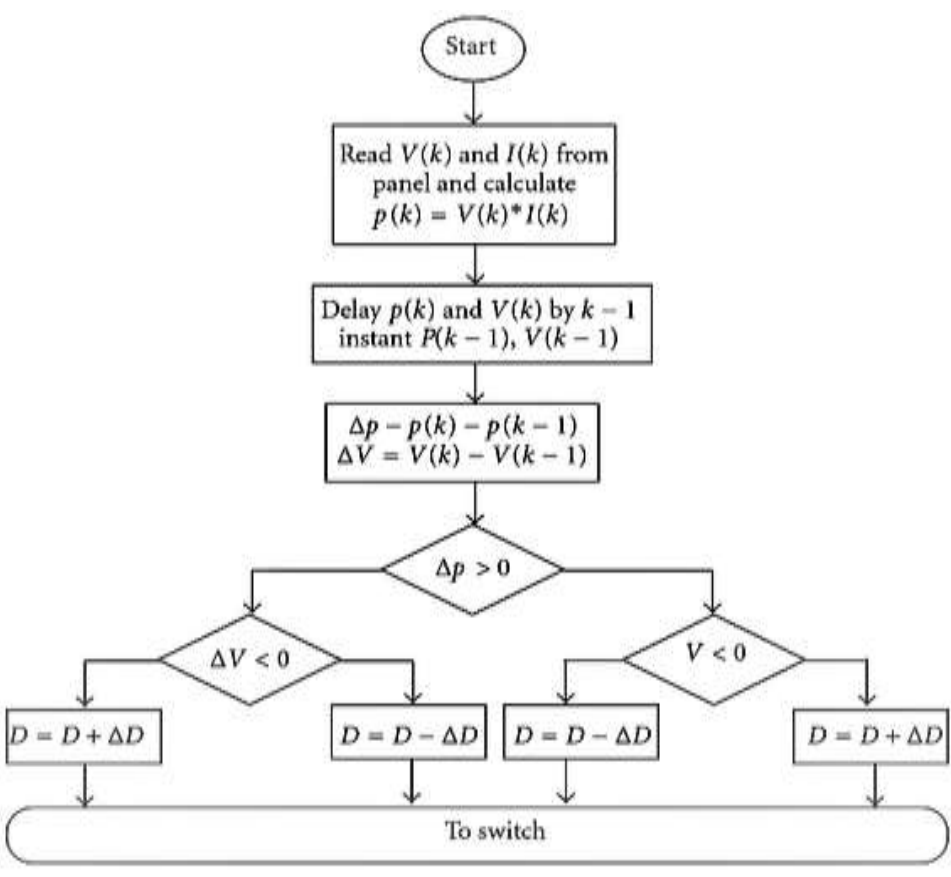

Fig 8. P\&O ba sic flow chart

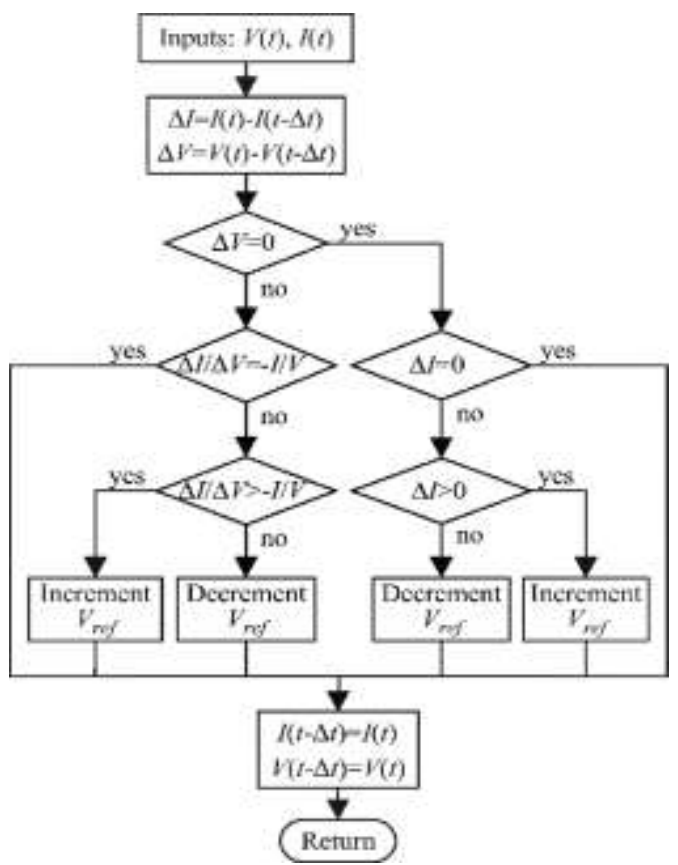

Fig 7. Incremental conductance flow chart

Incremental Conductance Method; Here it is used two voltage and current sensors, thus the internal controller will compare the array conductance and incremental conductance, and therefore, when these two values are closer to each other the array will operate at MPP voltage[30]. Fractional Open Circuit Voltage Method (FOCV); Under different irradiation conditions and temperatures, Vmpp is equal to Voc, and thus it is easy to obtain the MPP under each condition. Vmpp of solar cell is given by, Vmpp $=\mathrm{KVoc}$, where $\mathrm{K}$ is between 0.71 to 0.78 .

Apart from these common MPPT techniques, the below mentioned techniques will be also used[31],

1. Fractional short circuit current method

2. Fuzzy logic control

3. Neural network method

4. Look-up table technique

5. Hybrid MPPT method

6. MPPT for mismatched conditions

7. Analytical based MPPT method

8. Estimated perturb-perturb technique

Considering the Literature items above, the comparison of PV systems will be defined, designed and simulated in below chapters. 
International Journal of Advances in Scientific Research and Engineering (ijasre), Vol 6 (5), May -2020

\section{METHODOLOGY \& DESIGN}

As per the paper describes, it is proposed to use different albedo rates and tilt angles to perform the simulations. The location was selected as Colombo-Katunayaka Sri Lanka, and the main reason to use the location is because it is near the equator zone and thus it has no seasonal effects and more suitable for implementing solar power station due to its higher irradiance rate throughout the year. To design the solar power station it is used both bifacial and mono-facial solar panels with each 10kW installed capacity. The below table 1 described the complete solar power installation design parameters.

Table 1. Design characteristics bifacial and mono-facial

\begin{tabular}{lll}
\hline \multicolumn{1}{c}{ Component } & \multicolumn{1}{c}{ Description Bi-facial } & \multicolumn{1}{c}{ Description Mono-facial } \\
\hline Latitude & $7.71 \mathrm{oN}$ & $7.71 \mathrm{oN}$ \\
\hline Longitude & $79.88 \mathrm{oE}$ & $79.88 \mathrm{oE}$ \\
\hline Altitude & $8 \mathrm{~m}$ & $8 \mathrm{~m}$ \\
\hline Shading or obstacles & Considered as no shading effect & Considered as no shading effect \\
\hline Orientation & South-East & South-East \\
\hline Panel to panel spacing & $6.60 \mathrm{~m}$ & $6.60 \mathrm{~m}$ \\
\hline Total width & $3.04 \mathrm{~m}$ & $3.04 \mathrm{~m}$ \\
\hline PV module model & Mon-250Wp 60 cell & Mon-250Wp 60 cell \\
& bifacial & monofacial \\
\hline $\begin{array}{l}\text { Number of PV modules in } \\
\text { series }\end{array}$ & 10 & 10 \\
\hline Number of PV modules in & & 4 \\
parallel & 4 & 4 \\
\hline Total PV modules in system & 40 & 40 \\
\hline Array designed global power & $10 \mathrm{kWp}$ & $10 \mathrm{kWp}$ \\
\hline Array operating characteristics at 50oC & Umpp - 271V & Umpp - 271V \\
\hline Array area & Impp - 33A & Impp - 33A \\
\hline Inverter capacity & $65.1 \mathrm{~m} 2$ & $65.1 \mathrm{~m} 2$ \\
\hline Operating voltage & $4.2 \mathrm{kWac}$ with 2 MPPT & $4.2 \mathrm{kWac}$ with 2 MPPT \\
\hline Number of inverters & $125-500 \mathrm{~V}$ & $125-500 \mathrm{~V}$ \\
\hline DC/AC ratio & 2 & 2 \\
\hline
\end{tabular}

As per the above details, it is mentioned only the constant factors which didn't changed at any point during the simulations. The panel structure layout is shown in below figure 9 which was implemented by using SolidWorks software interface with all the dimensions. This design has eliminated the panel to panel shading and it is discussed in the results and analysis chapter in this paper.

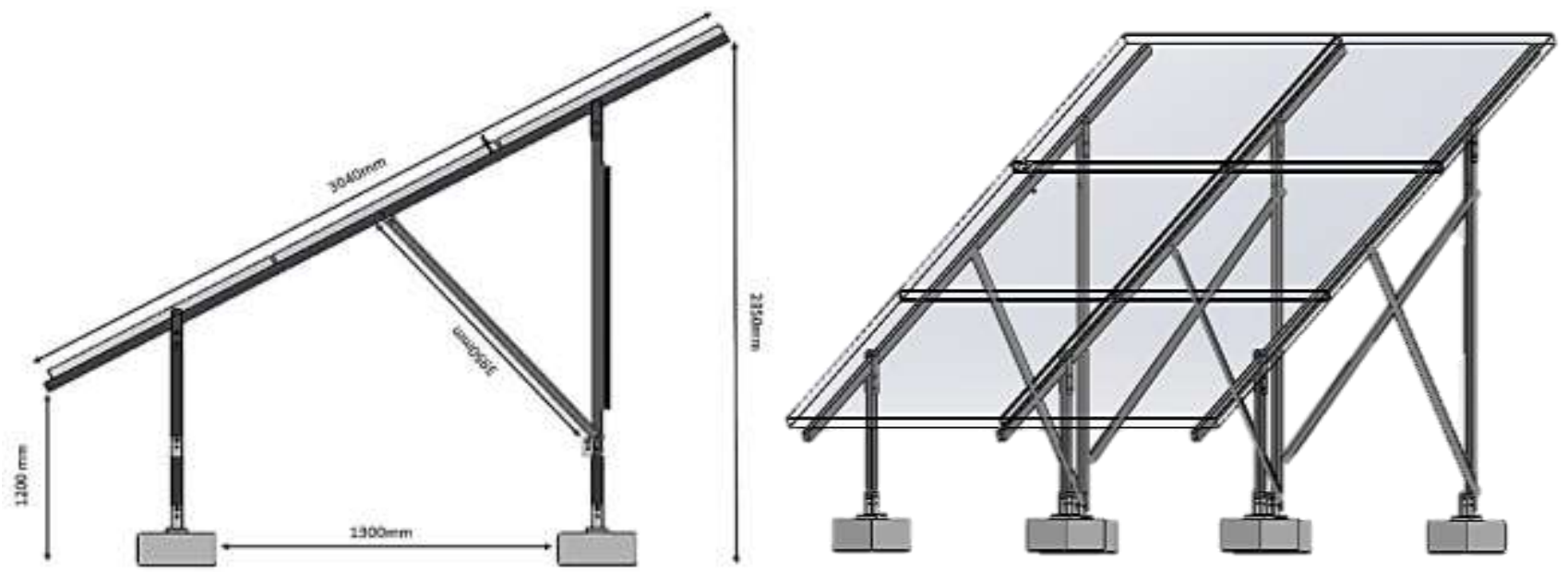

Fig. 9 Structure for ground mounted solar system

The photovoltaic panel ground mounted layout is shown in below figure 10. The gap between one shed to the other is 6.60 meters and used 30 degrees of tilt angle in the given design in order to display the visual layout clearly. 
International Journal of Advances in Scientific Research and Engineering (ijasre), Vol 6 (5), May -2020

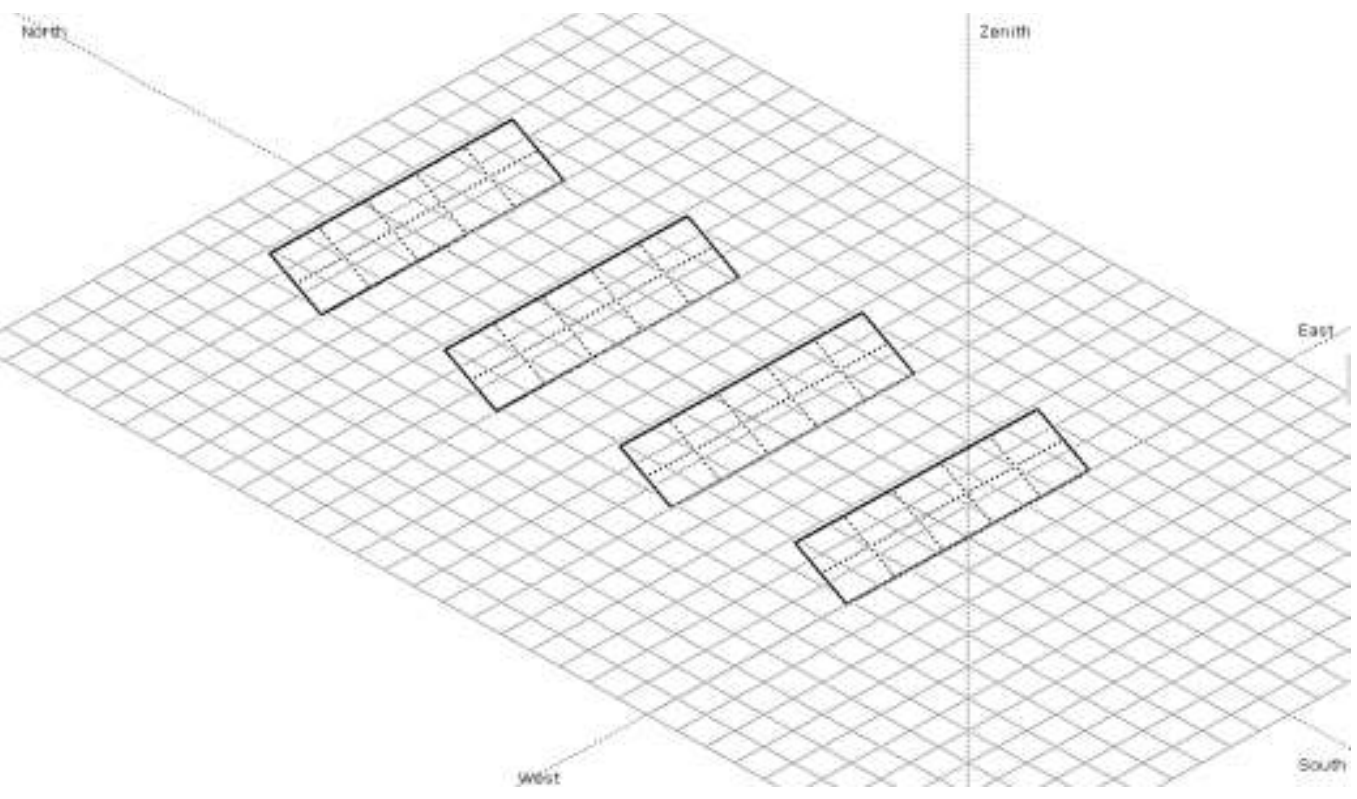

Fig 10. PV panel installation layout on ground mounted

According to the location, the sun path was observed as mentioned in below figure 11 with refer to the metrological data. This was also simulated for 30 degree tilt angle, and behind the plane is also considered since the sun path will be effect on both bifacial and mono-facial PV systems.

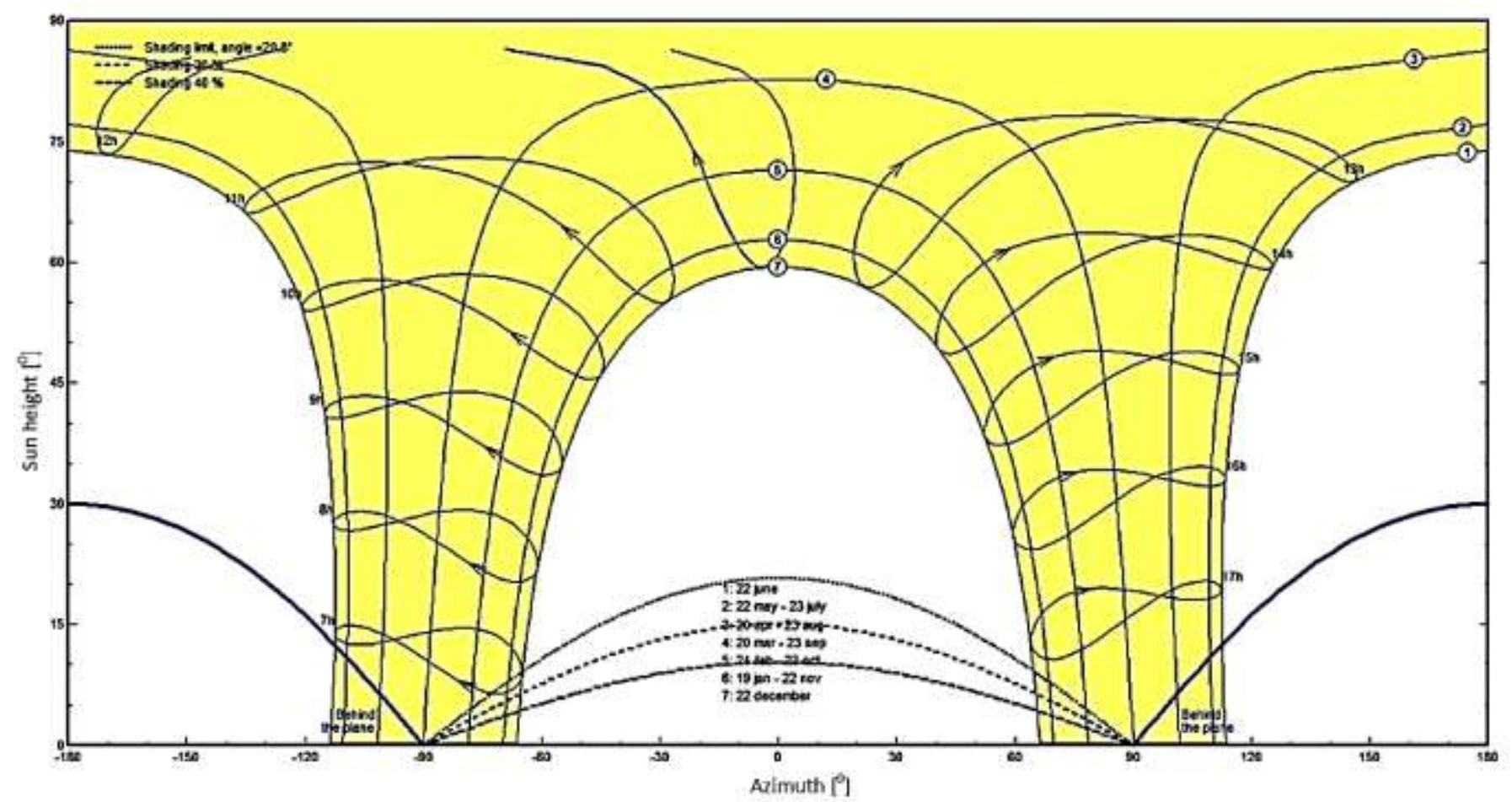

Fig 11. Sun path at Colombo Katunayake Sri Lanka

The irradiation is the most important factor in any solar power station location. Therefore, the below table 2 describes the irradiation levels, wind velocities and temperatures per day basis for all the 12 months. 
International Journal of Advances in Scientific Research and Engineering (ijasre), Vol 6 (5), May -2020

Table 2. Irradiation, temperature and wind velocities at location

\begin{tabular}{ccccc}
\hline Months & $\begin{array}{c}\text { Horizontal Global } \\
\text { irradiation } \\
\mathbf{k W h} / \mathbf{m}^{\mathbf{2}} \mathbf{. d a y}\end{array}$ & $\begin{array}{c}\text { Horizontal Diffuse } \\
\text { irradiation } \\
\mathbf{k W h} / \mathbf{m}^{\mathbf{2} . \mathbf{d a y}}\end{array}$ & $\begin{array}{c}\text { Temperature } \\
\mathbf{0} \mathbf{C}\end{array}$ & $\begin{array}{c}\text { Wind velocity } \\
\mathbf{~} / \mathbf{s}\end{array}$ \\
\hline January & 5.13 & 2.39 & 27.2 & 4.20 \\
\hline February & 5.59 & 2.47 & 26.9 & 3.00 \\
\hline March & 6.01 & 2.48 & 27.6 & 2.50 \\
\hline April & 5.82 & 2.51 & 27.3 & 2.30 \\
\hline May & 5.04 & 2.80 & 28.5 & 3.80 \\
\hline June & 5.16 & 2.80 & 27.5 & 4.40 \\
\hline July & 5.19 & 2.42 & 27.8 & 4.20 \\
\hline August & 5.28 & 2.63 & 27.7 & 4.40 \\
\hline September & 5.26 & 2.54 & 27.0 & 3.60 \\
\hline October & 5.20 & 2.25 & 26.9 & 2.80 \\
\hline November & 5.02 & 2.28 & 26.0 & 2.50 \\
\hline December & 4.32 & 2.00 & 25.4 & 3.50 \\
\hline
\end{tabular}

This, system is not mainly focus on MPPT tracking system since it is not the main point of discussion. Even though, it is designed a 250Wp panel from the used equivalent circuit and then created P\&O MPPT algorithm to obtain MPPT function of PV panels. The below figures shows the $250 \mathrm{Wp}$ PV panel designing using MATLAB/Simulink software interface. All the steps shown clearly thus for the possibility of repeating the same work by the reader. The equations 4,5,6 and 11 are used for designing.

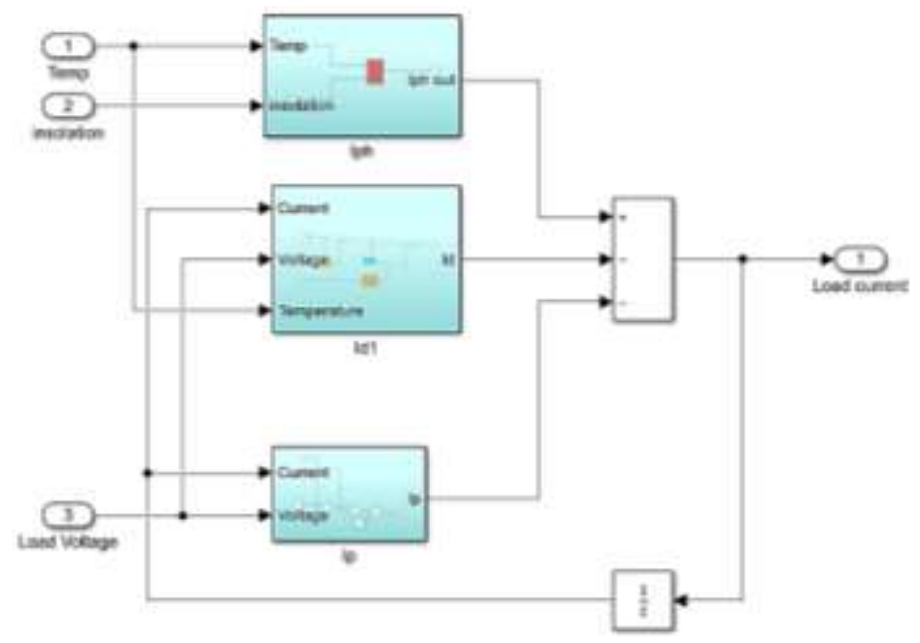

Fig 12. PV panel design, Iph, Id and Ip parameters

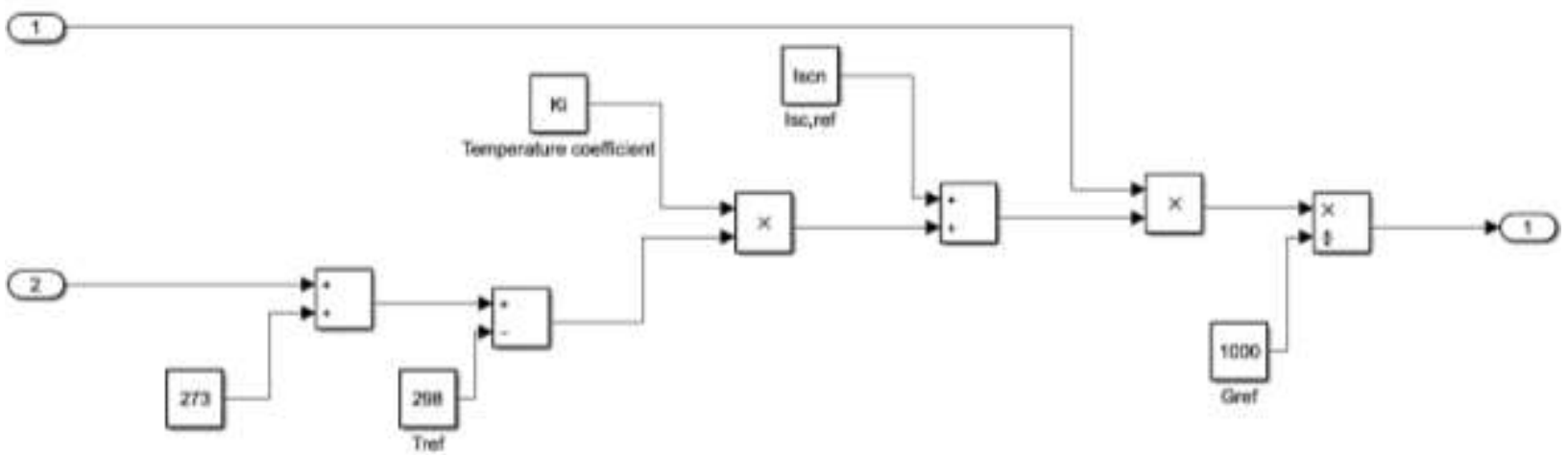

Fig 13. Iph Subsystem 
International Journal of Advances in Scientific Research and Engineering (ijasre), Vol 6 (5), May -2020

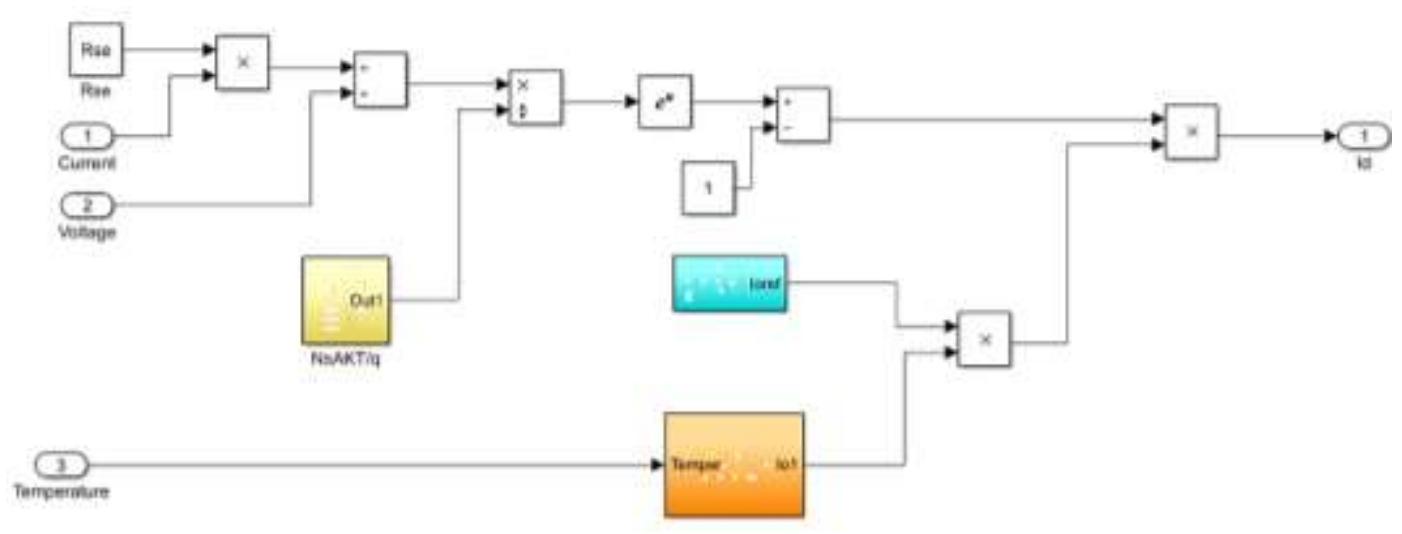

Fig 14. Id Subsystem

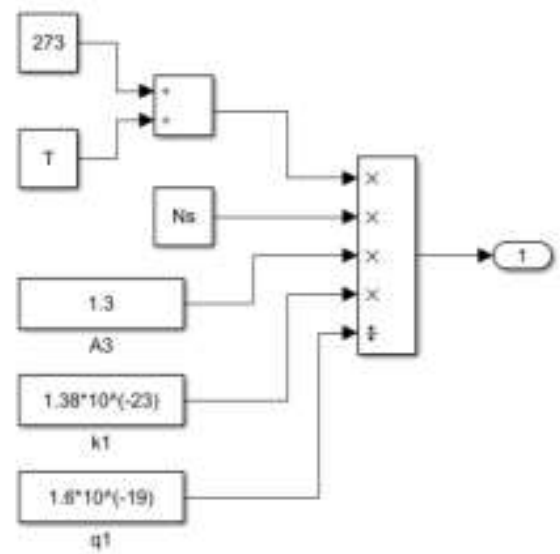

Fig 15. Modified ideality factor (a); block NsAKtc/q

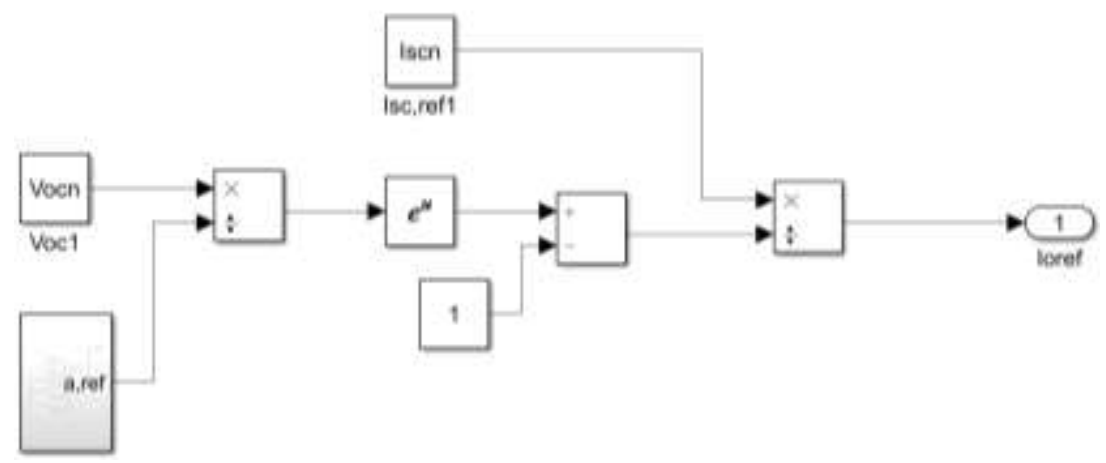

Fig 16. Io,ref subsystem

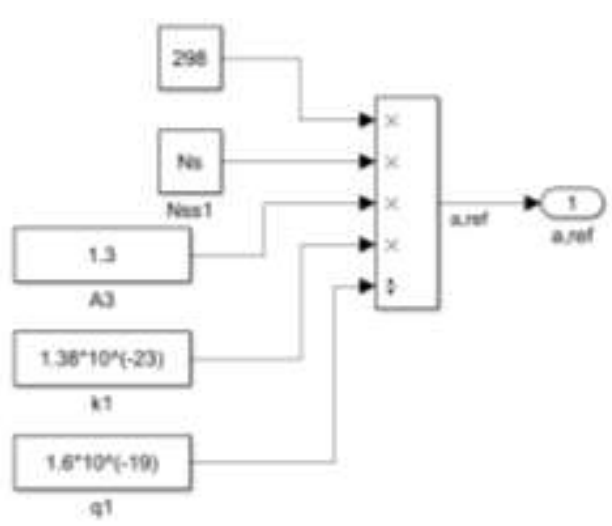

Fig 17. a,ref subsystem 
International Journal of Advances in Scientific Research and Engineering (ijasre), Vol 6 (5), May -2020

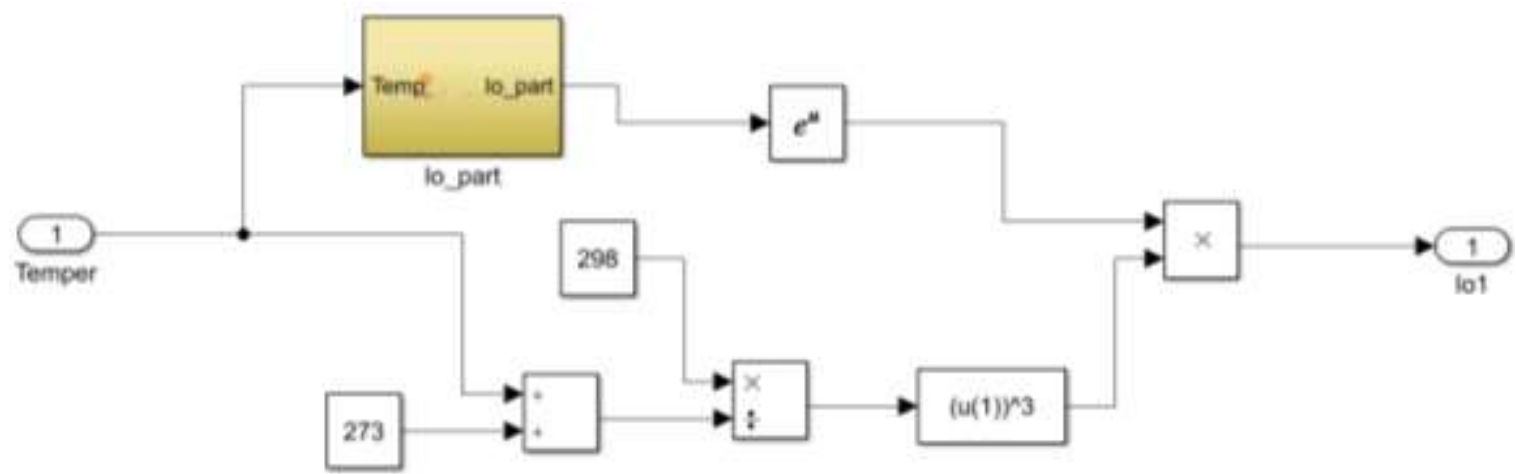

Fig 18. Io temperature block

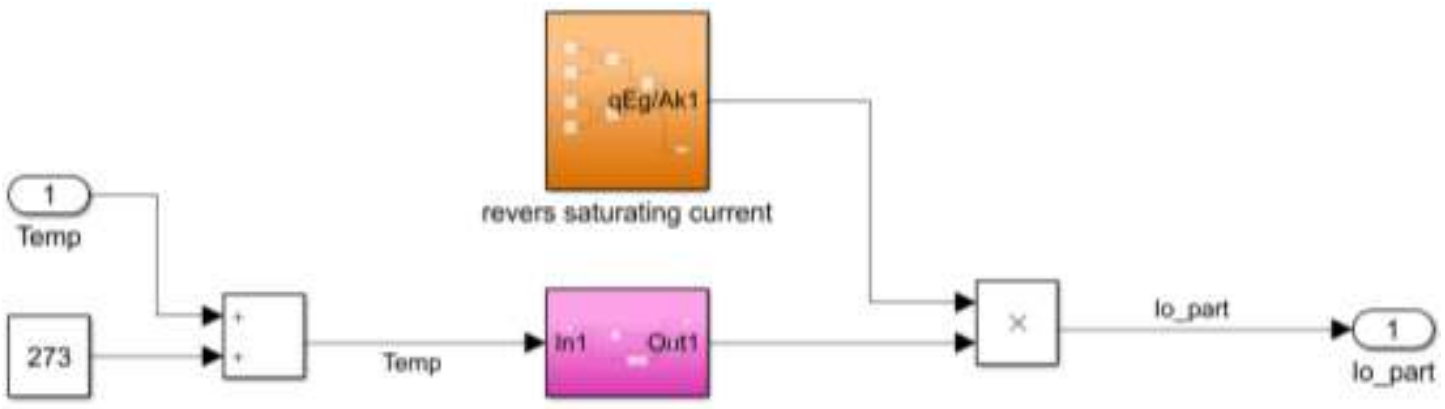

Fig 19. Io_part block subsystem

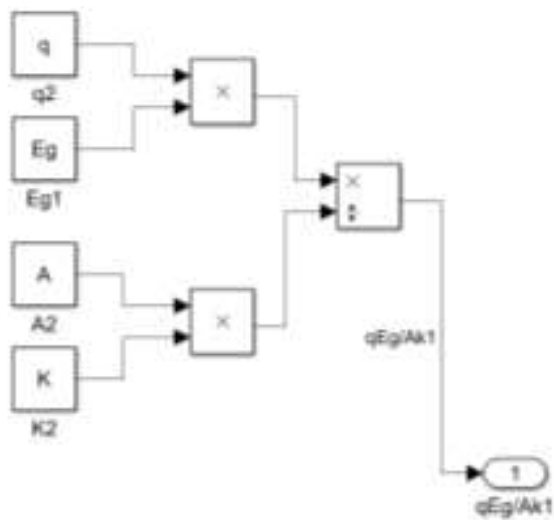

Fig 20. Revers saturating current block subsystem

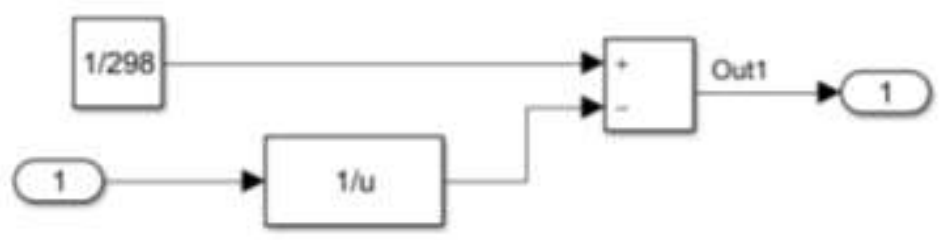

Fig 21. Temperature In and out block subsystem for obtaining Io 
International Journal of Advances in Scientific Research and Engineering (ijasre), Vol 6 (5), May -2020

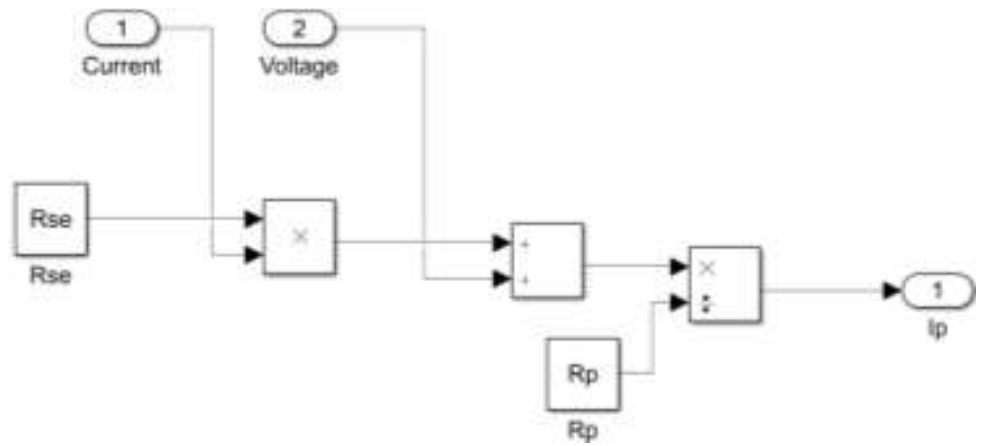

Fig 22. Ip block subsystem

Using the above Simulink configuration it can be designed a PV module as per the requirement. All the factors influencing the PV characteristics was well observed and shown accordingly. To create the MPPT system it is design the MPPT algorithm as shown in below figure.

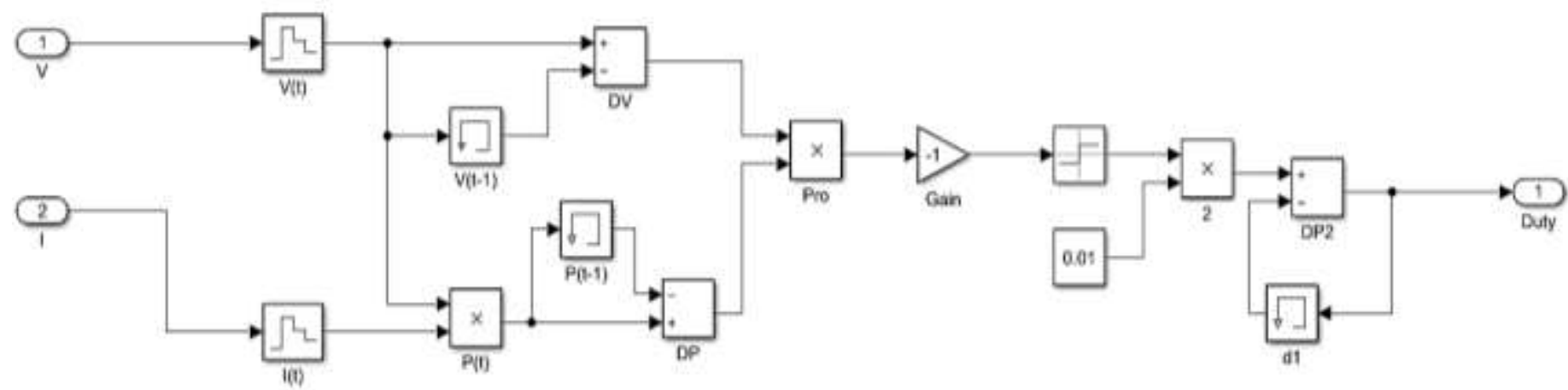

Fig 23. P\&O MPPT algorithm design

To analyze the MPPT function, it was given a trapezoidal signal as irradiance as shown in below figure by keeping temperature constant.

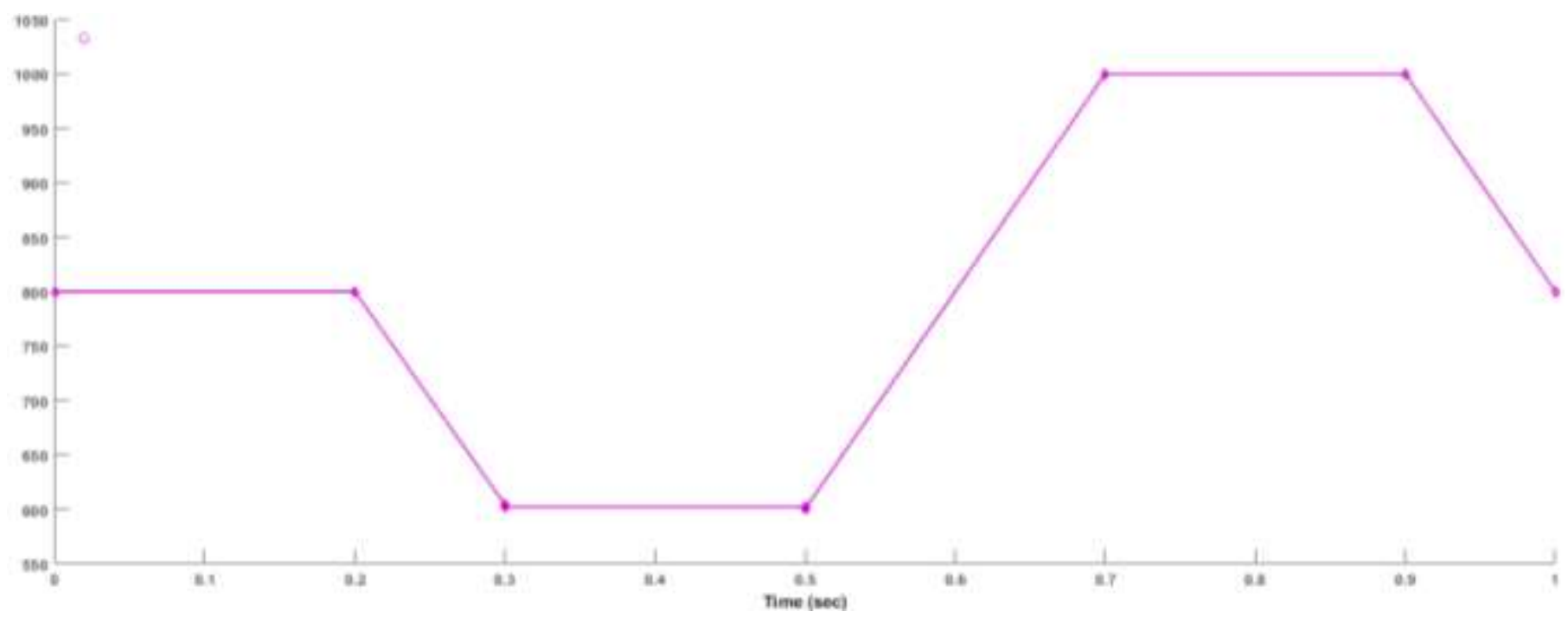

Fig 24. Irradiation changes with time

Therefore, the complete PV MPPT system with DC-DC Boost converter for 250Wp panel can be shown as below figure. 


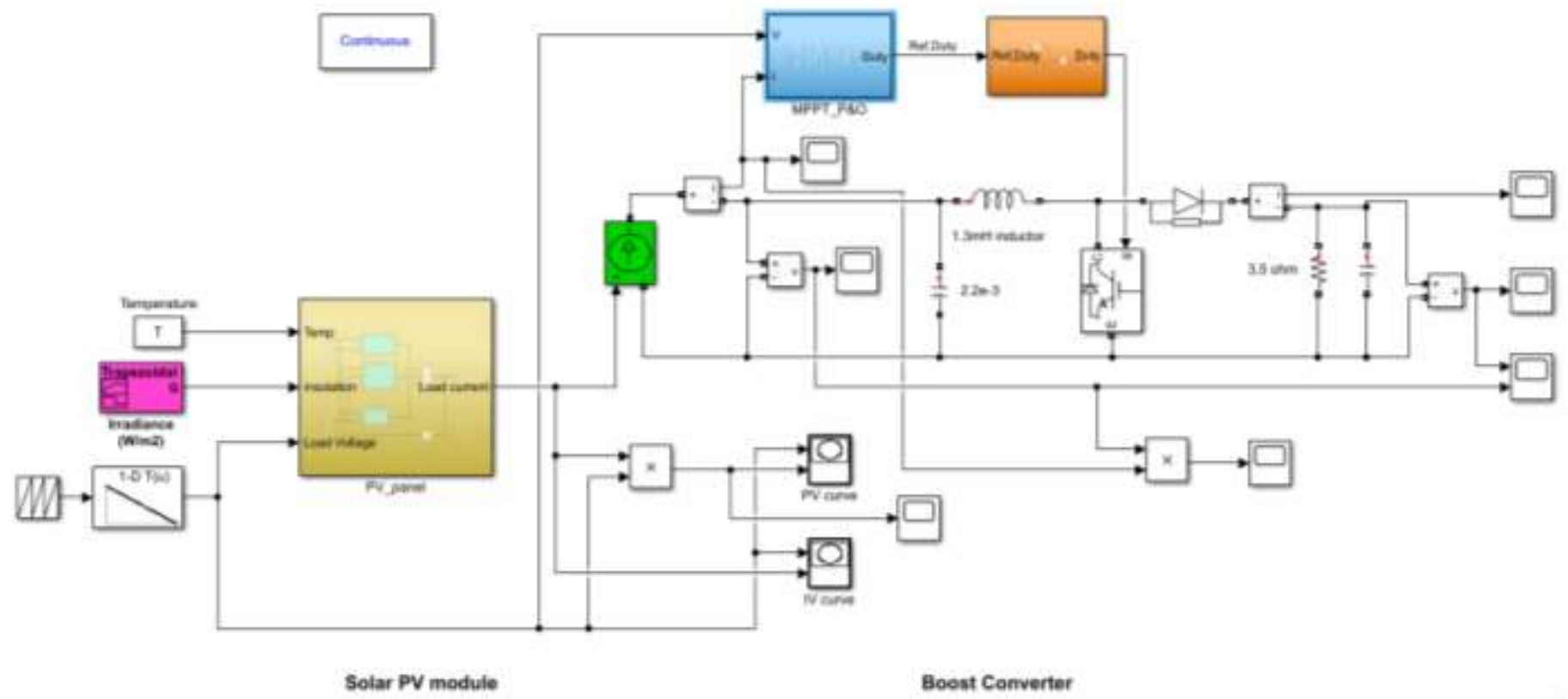

Fig 25. PV_MPPT with boost converter

For the above PV system design the initialization functions are as follows, $\mathrm{k}=1.38 \mathrm{e}-23, \mathrm{q}=1.602 \mathrm{e}-19$, Iscn=8.6, Vocn=42, $\mathrm{Ki}=0.0032, \mathrm{Ns}=72, \mathrm{~A}=1.3, \mathrm{Eg}=1.12, \mathrm{Rse}=0.221, \mathrm{Rp}=415.405$

These were the initial considerations before the simulation of power generation and analyzing the mono-facial and bifacial solar panel influences on power generation increments. The data should be more reliable so that it can create high resolution of readings and low error weighting factor that will result in more accuracy in power production estimation.

\section{SIMULATION AND ANALYSIS}

The PV design will be sectioned into two which will be 10KW bifacial solar power system and 10KW mono-facial solar power system. The simulations will be conducted under 4 variable considerations, such as a. Albedo 30 and tilt angle 15, b. Albedo 30 and tilt angle 30, c. Albedo 80 and tilt angle 15, d. Albedo 80 and tilt angle 30 on both sections. Initially it is simulated the MPPT operation at different irradiation levels to make sure the panels used for the simulations will generate maximum power at every irradiation level.

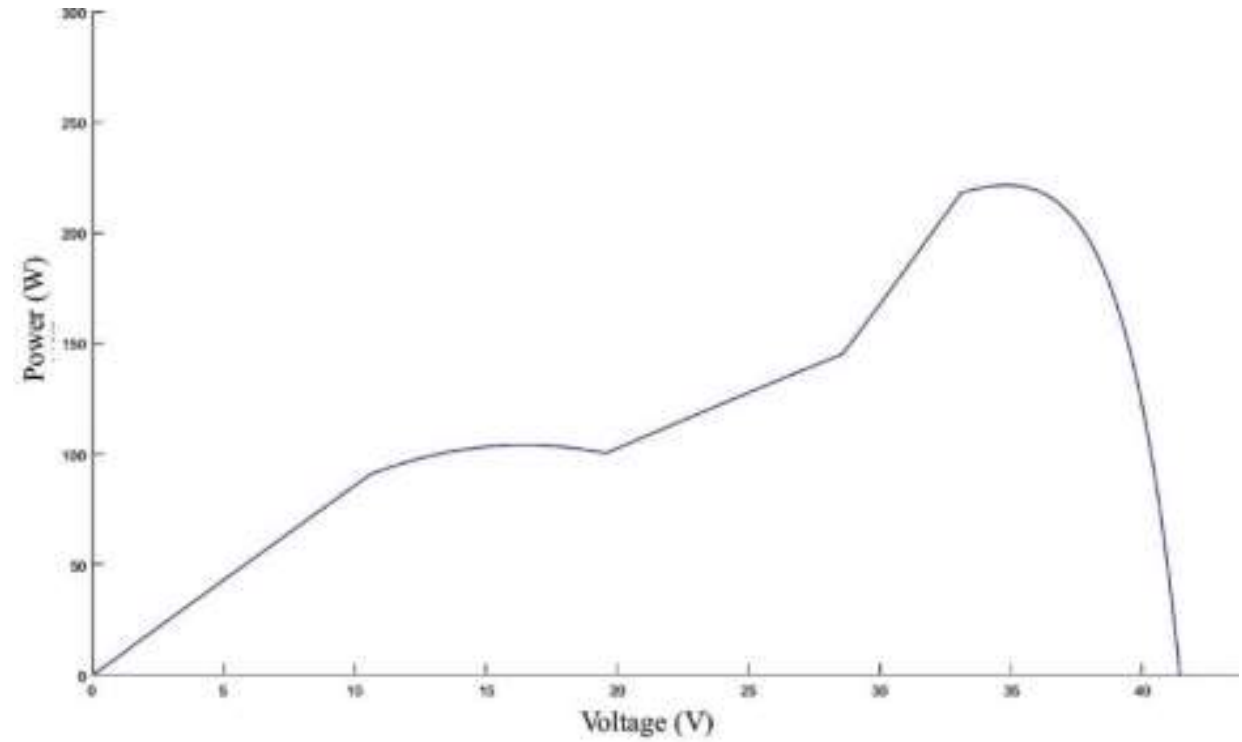

Fig. 26. PV curve of $250 \mathrm{~W}$ panel under different irradiation 


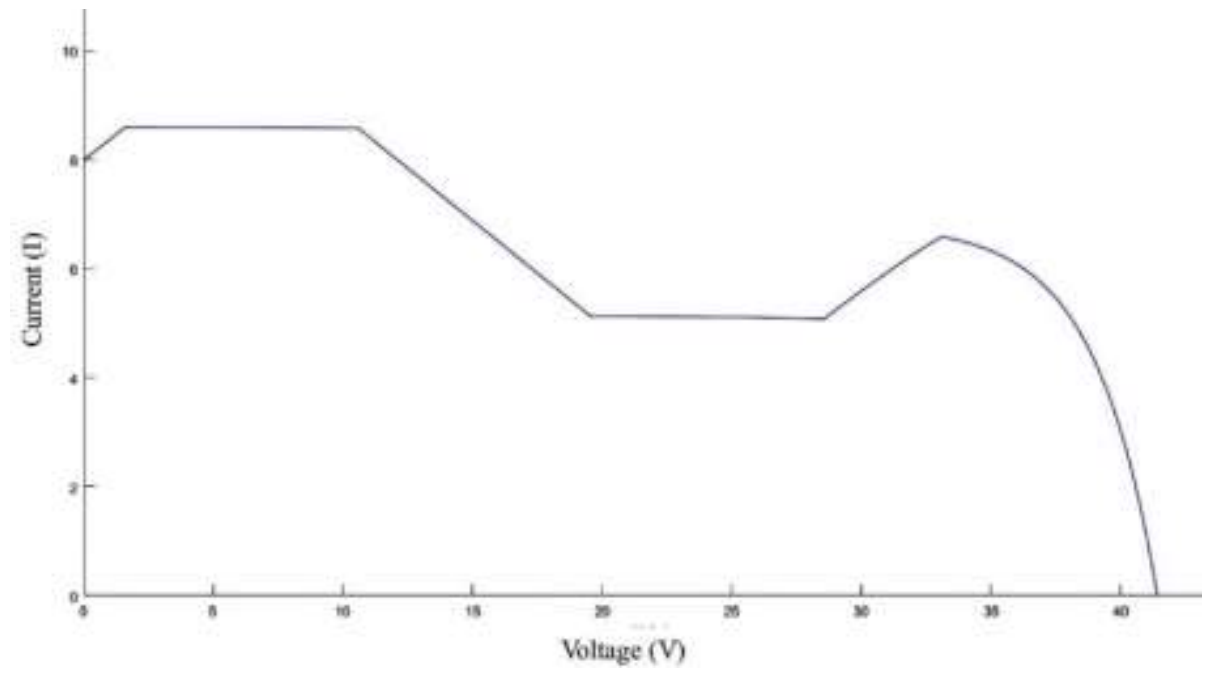

Fig. 27. IV curve of $250 \mathrm{~W}$ panel under different irradiation

With MPPT implementation and boost converter system, the power output at different irradiation levels will be as follow,

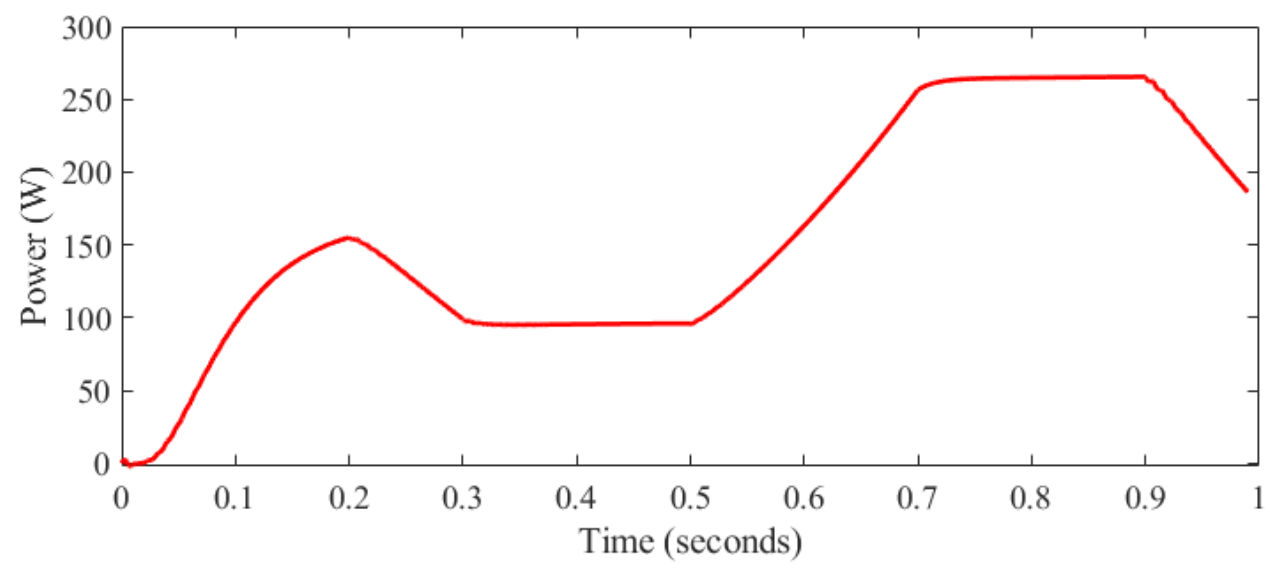

Fig. 28. Power output at PV with MPPT

The Figure29. represents the PV voltage at MPPT with boost converter output voltage.

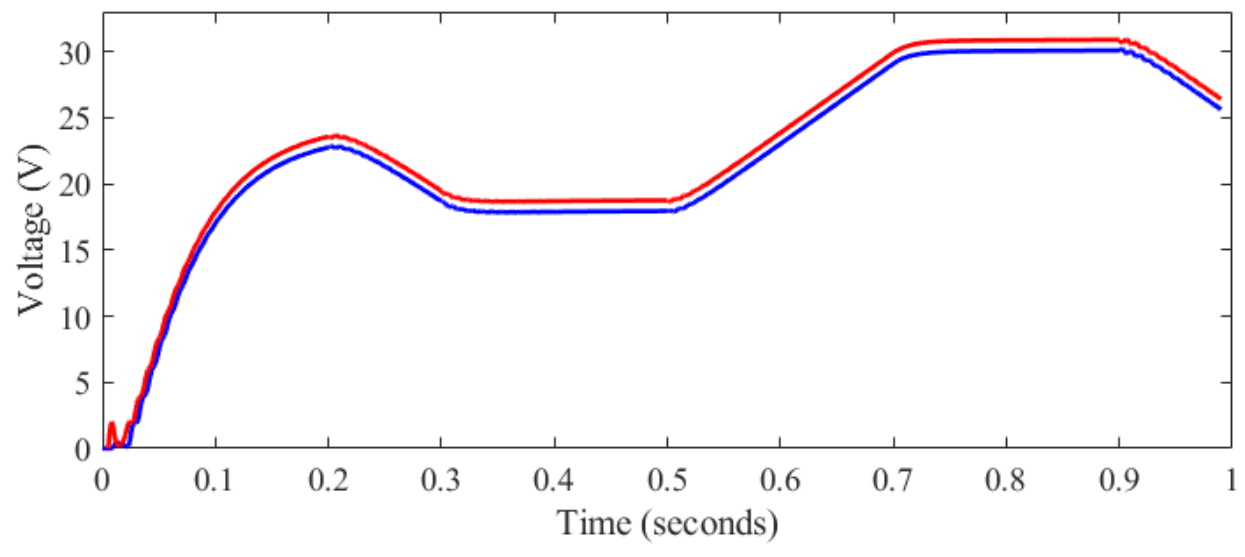

Fig. 29. MPPT voltage tracking under different irradiation levels

Output voltage is slightly lower than the input voltage by the PV, thus it is much closer and therefore it operates under maximum power.

The variation and tracking of current under different irradiations are mentioned in below figure, 


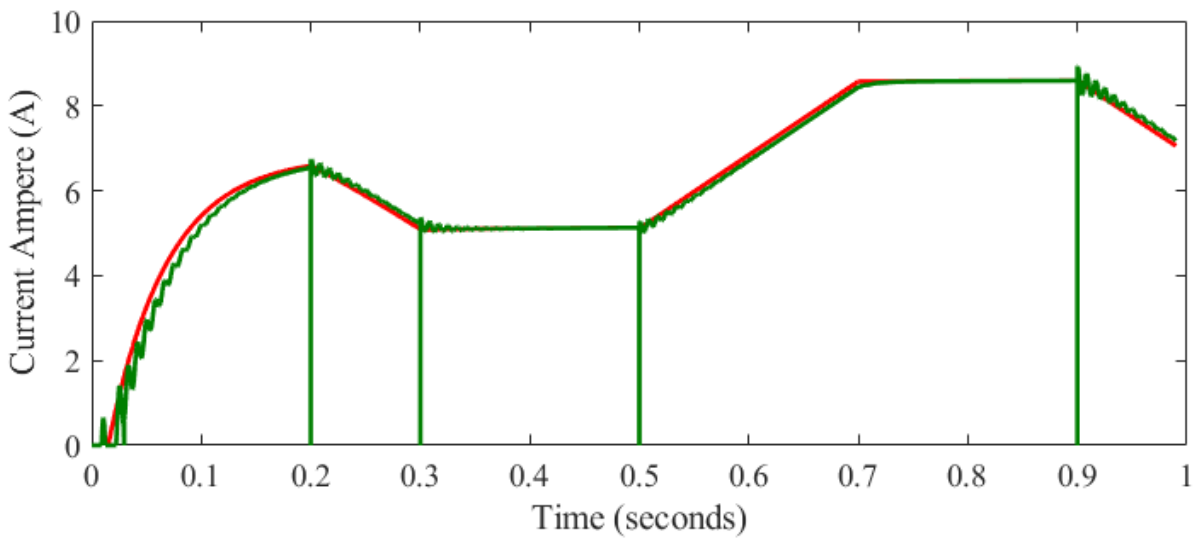

Fig. 30. MPPT current tracking under different irradiation levels

The current at MPPT is obtained, thus it is clear that P\&O method has some instability in MPPT detection and creates some ripple which is one of the drawbacks of this method. This is also known as Steady state oscillation near MPP. Since the main outline of this paper is focused on performance of Bi-facial panels and mono-facial panels, further discussions of MPPT for improving these drawbacks have not been discussed. Thus, this is to understand that the PV panel which was implemented in Simulink is performing as a standard P\&O MPPT implemented PV power system.

Furthermore, the PV ground mounting layout and the mounting structure was designed to avoid the shading effect of panel to panel at any point. Therefore, partial shading due to panel to panel shadings can be eliminated at site. The below Fig. 31 and 32 represents the distances of PV and the non-shading effect per day with shading limit angle of 20.8 degree at 30 degree tilt angle.

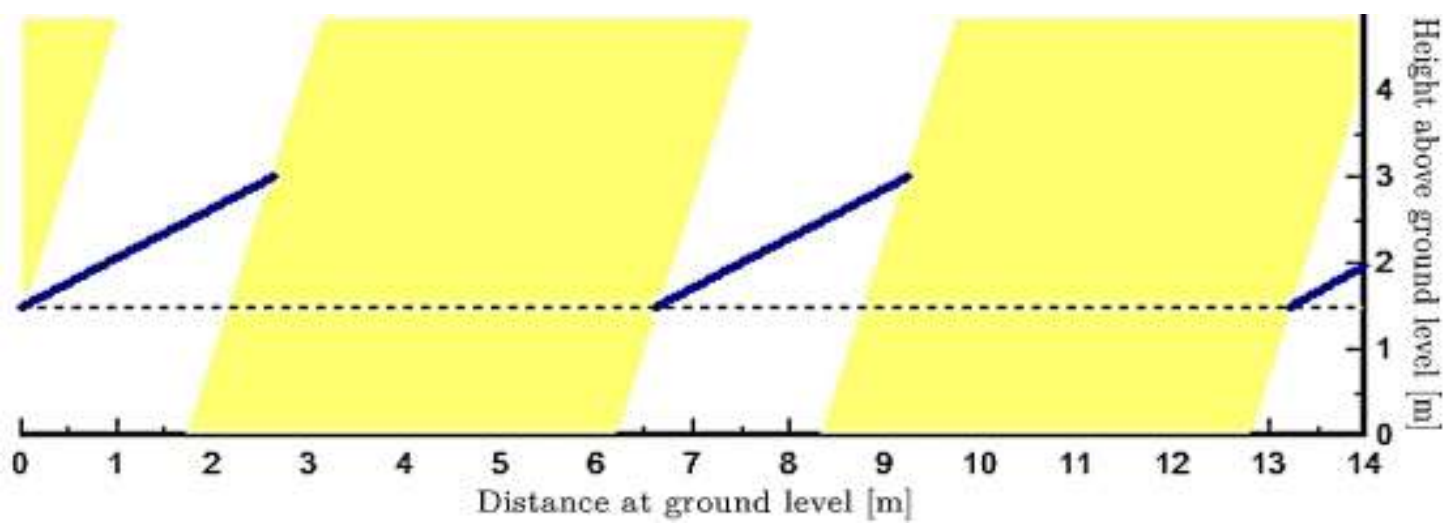

Fig. 31. Ground distance and sun path

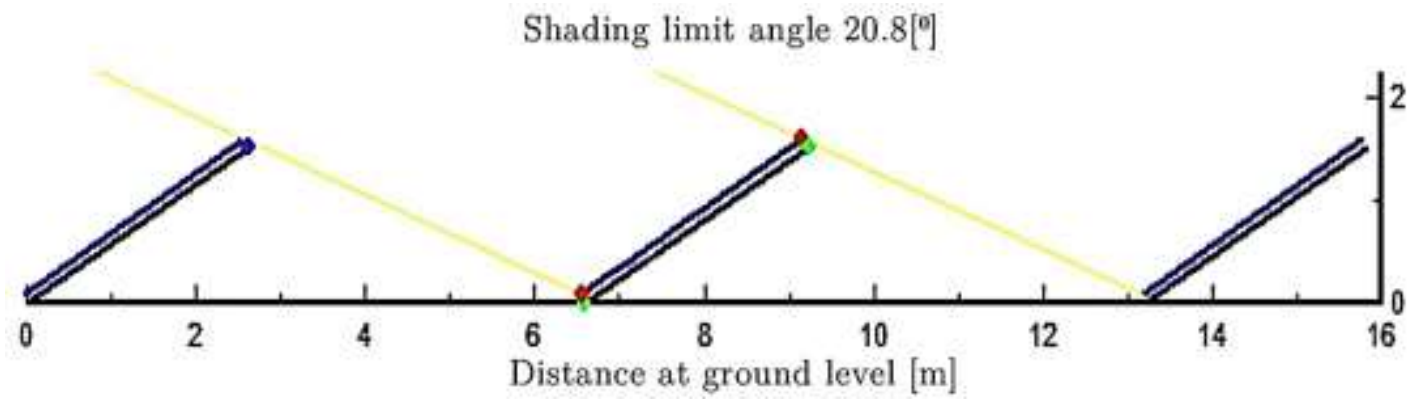

Fig. 32. Shading limit angle and ground distance

To observe the variation of reflection on rear side of the bifacial panel, the below simulations were done as mentioned in below table. 
International Journal of Advances in Scientific Research and Engineering (ijasre), Vol 6 (5), May -2020

Table 3. Reflection on rear side of bifacial panel under different albedo and tilt angles

\begin{tabular}{c|cc}
\hline \multirow{2}{*}{ Albedo and tilt angles } & \multicolumn{2}{|c}{ Irradiation on rear side $\mathbf{k W h} / \mathbf{m}^{\mathbf{2}} /$ annual } \\
\cline { 2 - 3 } & Reflected on back & Sky reflection on back \\
\hline Albedo 30 - Tilt 30 & $243 \mathrm{kWh} / \mathrm{m}^{2}$ & $32 \mathrm{kWh} / \mathrm{m}^{2}$ \\
\hline Albedo 30 - Tilt 15 & $242 \mathrm{kWh} / \mathrm{m}^{2}$ & $5 \mathrm{kWh} / \mathrm{m}^{2}$ \\
\hline Albedo 80 - Tilt 30 & $648 \mathrm{kWh} / \mathrm{m}^{2}$ & $32 \mathrm{kWh} / \mathrm{m}^{2}$ \\
\hline Albedo 80 - Tilt 15 & $645 \mathrm{kWh} / \mathrm{m}^{2}$ & $5 \mathrm{kWh} / \mathrm{m}^{2}$ \\
\hline
\end{tabular}

According to the above results, the tilt angle changing from 15 to 30 degrees does not affect much on the rear side reflections thus the sky reflection has increased from $5 \mathrm{kWh} / \mathrm{m}^{2}$ to $32 \mathrm{kWh} / \mathrm{m}^{2}$. Albedo increasing from 30 to 80 has increased the reflection rates significantly, and therefore, it is clear that the albedo rate has much influence on rear side bifacial gain in a bifacial photovoltaic panel. The below images shows the irradiance spread in 30 degrees and 15 degrees of tilt angles thus to clearly show the sun rays distribution after reflection.

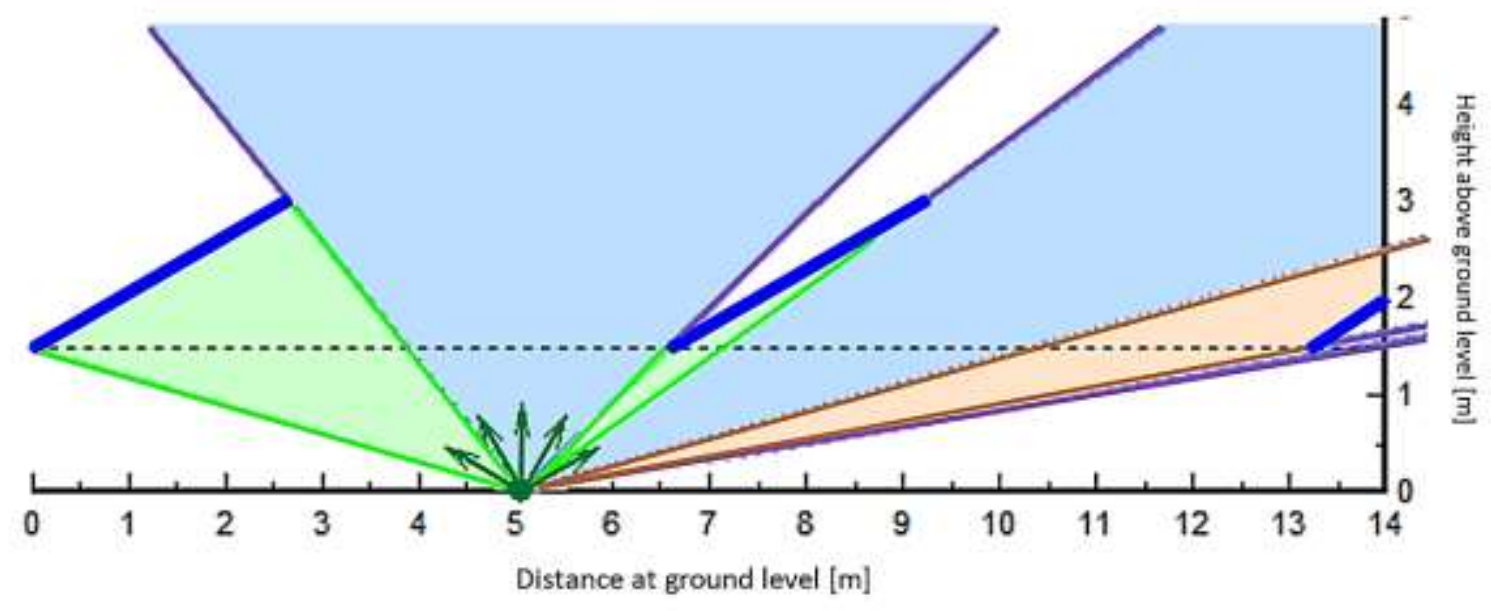

Fig. 33. Tilt angle of 30 (reflection distribution)

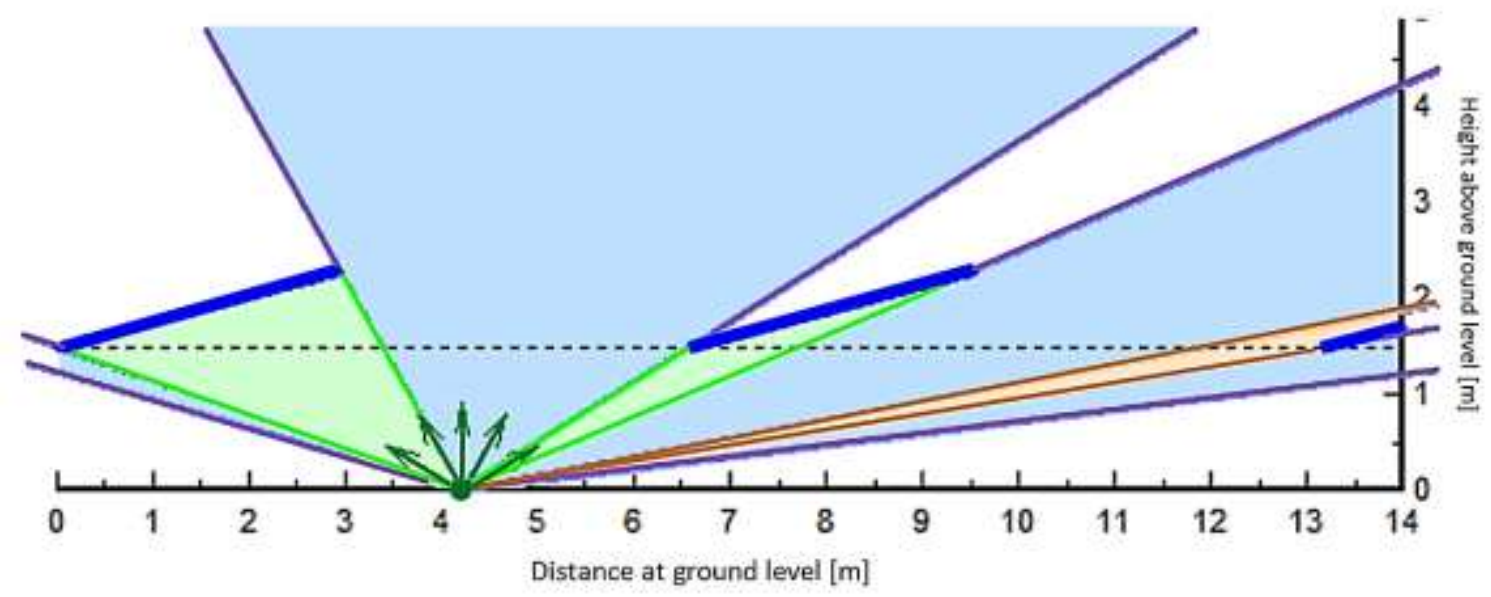

Fig. 34. Tilt angle of 15 (reflection distribution)

With the above views of irradiation distribution with respect to the reflections, the below table of view factors can be developed for all the tilt angles and albedo rates. The values are calculated in average, since the point of irradiation on ground which is denoted in green arrows will be varied at every point throughout the sun path. 
International Journal of Advances in Scientific Research and Engineering (ijasre), Vol 6 (5), May -2020

Table 4. View factors at different albedo and tilt angles

\begin{tabular}{ccccc}
\hline $\begin{array}{c}\text { Albedo and tilt } \\
\text { angles }\end{array}$ & $\begin{array}{c}\text { View factor to back } \\
\text { average \% }\end{array}$ & $\begin{array}{c}\text { View factor to front } \\
\text { average \% }\end{array}$ & $\begin{array}{c}\text { Diffuse on } \\
\text { ground \% }\end{array}$ & $\begin{array}{c}\text { Reflected diffuse on } \\
\text { back \% }\end{array}$ \\
\hline $\begin{array}{c}\text { Albedo 30 } \\
\text { Tilt 30 }\end{array}$ & 39.1 & 1.5 & 60.5 & 7.1 \\
\hline $\begin{array}{c}\text { Albedo 30 - } \\
\text { Tilt 15 }\end{array}$ & 42.5 & 0.3 & 54.8 & 7 \\
\hline $\begin{array}{c}\text { Albedo } 80- \\
\text { Tilt 30 }\end{array}$ & 39.1 & 1.5 & 57 & 17.8 \\
\hline $\begin{array}{c}\text { Albedo } 80- \\
\text { Tilt 15 }\end{array}$ & 42.5 & 0.3 & 54.8 & 18.7 \\
\hline
\end{tabular}

The view factor at back is always higher at 15 degrees of tilt angle and vice versa, the view factor in front side is higher at 30 degrees of tilt angle. Diffuse on ground values are much similar in every scenario, thus, reflected diffuse on back is always higher during higher albedo rates. Therefore, as per the simulation results, the albedo 80 with tilt angle of 15 is more effective on irradiation capturing at site. The view factor, global incident on ground, ground reflection loss, global irradiance on rear side and horizontal global irradiation in above 4 simulations are shown in below Figures.

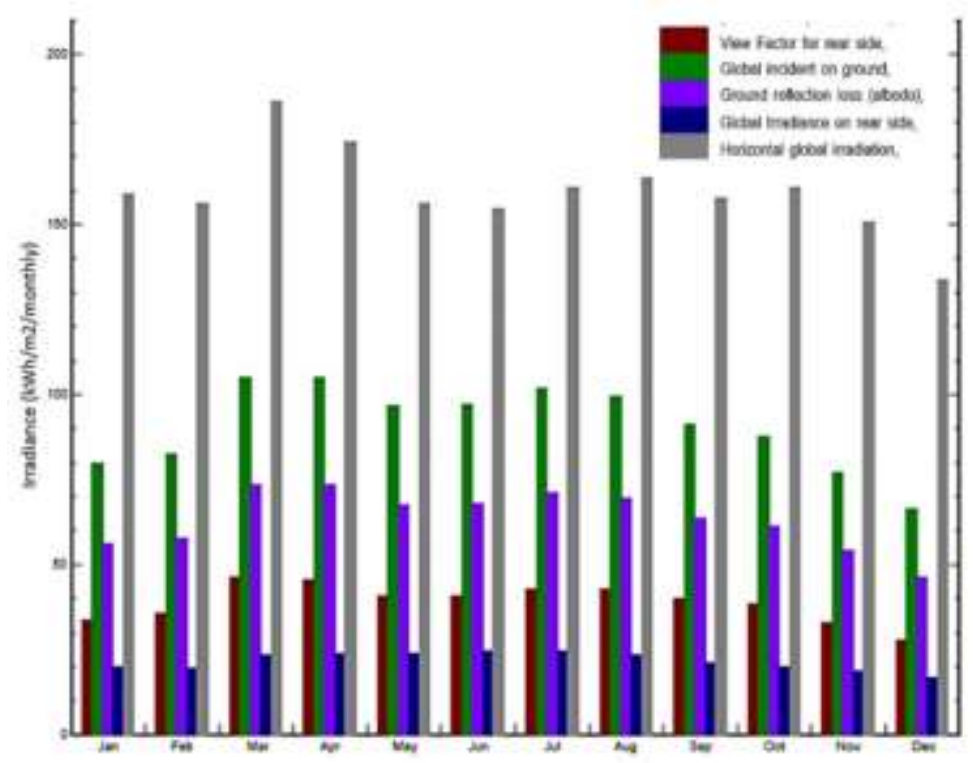

Fig 35. Albedo 30 tilt 30

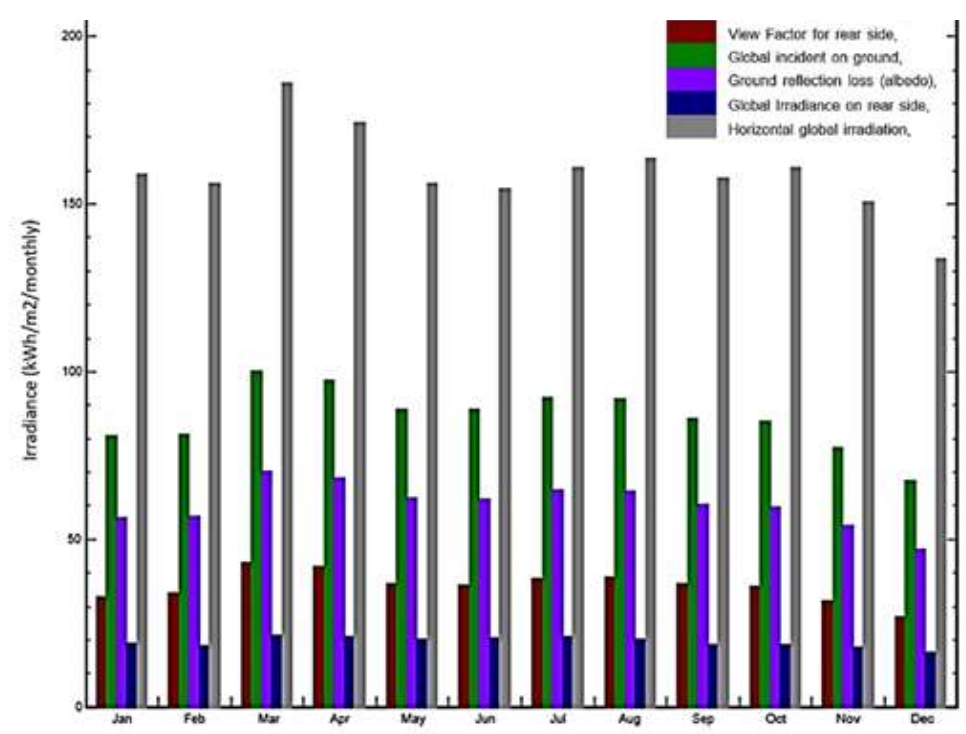

Fig 36. Albedo 30 tilt 15 


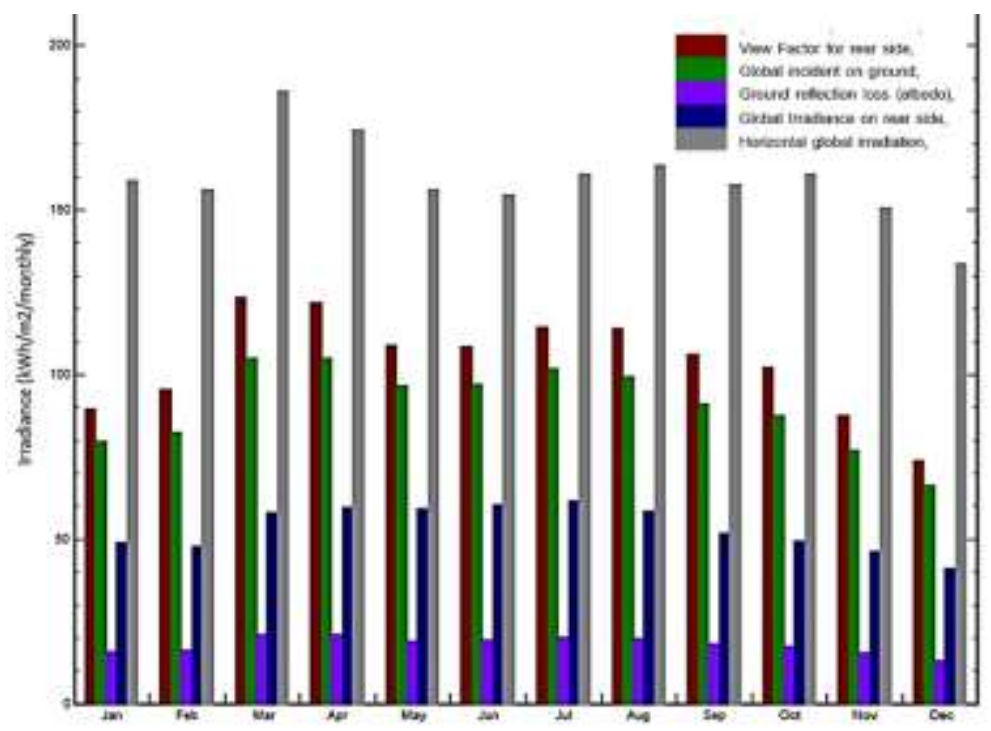

Fig 37. Albedo 80 tilt 30

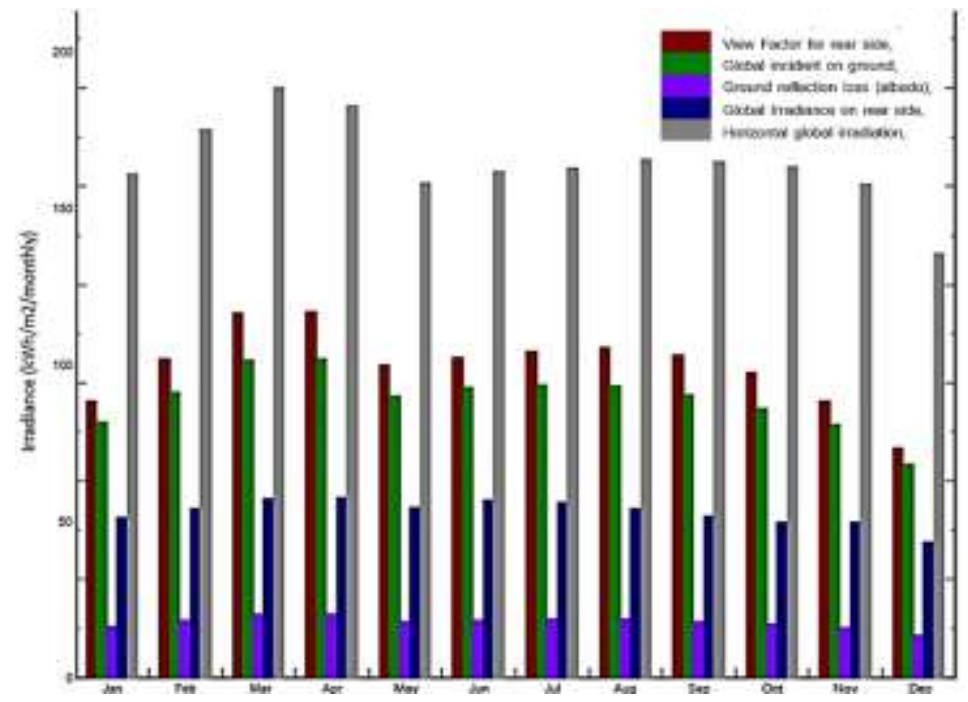

Fig 38. Albedo 80 tilt 15

In every situation the horizontal global irradiation is equal since it is observed under same climate condition. The ground reflection loss is significantly reduced in higher albedo rate of 80 and it has also increased the view factor and the global irradiance on rear side.

The mono-facial photovoltaic panels has no any effect on rear side irradiation gain, and therefore, the view factor rear side, global reflections on rear side and the irradiance on rear side of the panel is not considered. Even though, the irradiation on front side is important and it is same as the horizontal global irradiation in above bifacial simulations. With respect to this, the below table expose the generation rates on mono-facial solar panels of $10 \mathrm{~kW}$ at both 30 degrees and 15 degrees tilt angles.

Table 5. 10kW Mono-facial solar panels generation per year

\begin{tabular}{ccc}
\hline Tilt angle & Produced energy & Performance ratio \\
\hline 30 degrees mono-facial PV & $15.08 \mathrm{MWh} /$ year & $79.06 \%$ \\
\hline 15 degrees mono-facial PV & $15.37 \mathrm{MWh} /$ year & $79.15 \%$ \\
\hline
\end{tabular}

The loss diagrams for both conditions for one whole year is mentioned in below Figures. 
International Journal of Advances in Scientific Research and Engineering (ijasre), Vol 6 (5), May -2020

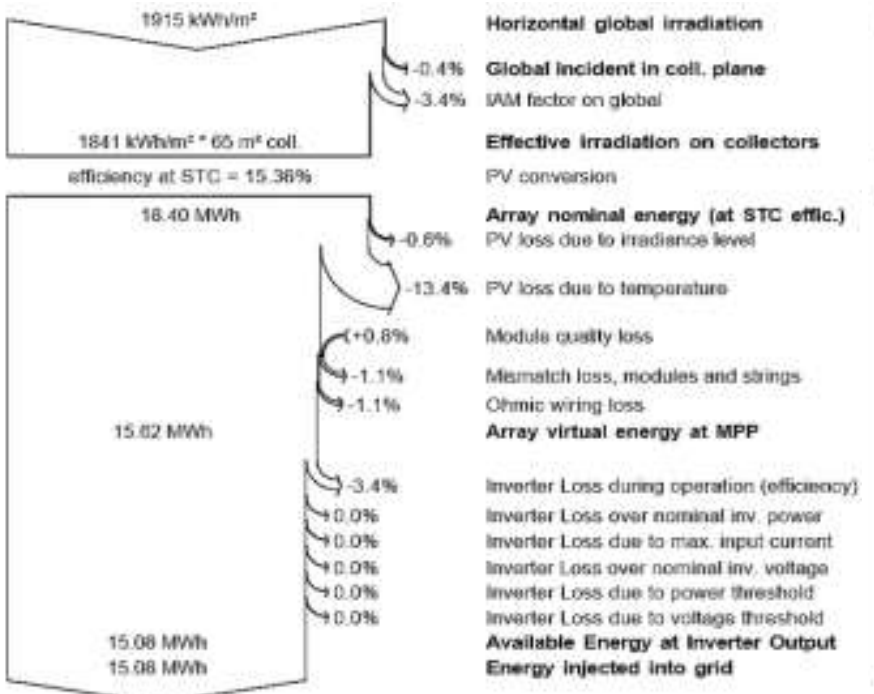

Fig 39. Loss graph for 30 degrees tilt mono PV

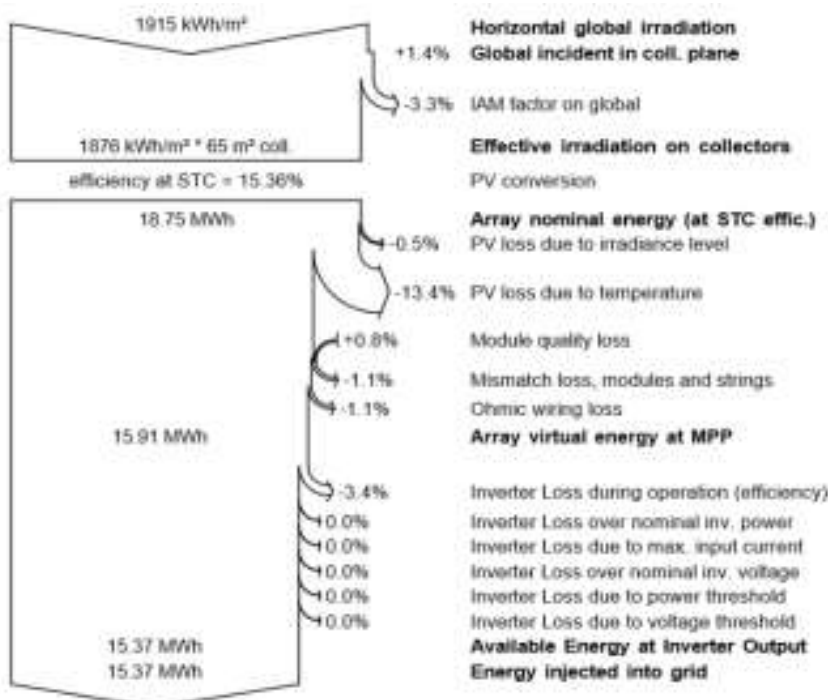

Fig 40. Loss graph for 15 degrees tilt mono PV

The produced energy per year in both conditions are almost similar. Therefore, in a PV power station development using a monofacial photovoltaic panels, it can be use any value for the tilt angle between 15 degrees to 30 degrees as per the site conditions. The loss diagram has included temperature losses, wiring losses, inverter losses and mismatch losses and given an approximate loss diagram for the specific power conditions per year.

As for the comparison analysis it is important to check the bifacial solar power generation throughout the year with the gain of rear side of the panel. Therefore, the below table express the simulation results of the power generation and performance ratio of bifacial solar power system of $10 \mathrm{~kW}$ under the conditions which it was done before.

Table 6. 10kW bifacial solar panels generation per year

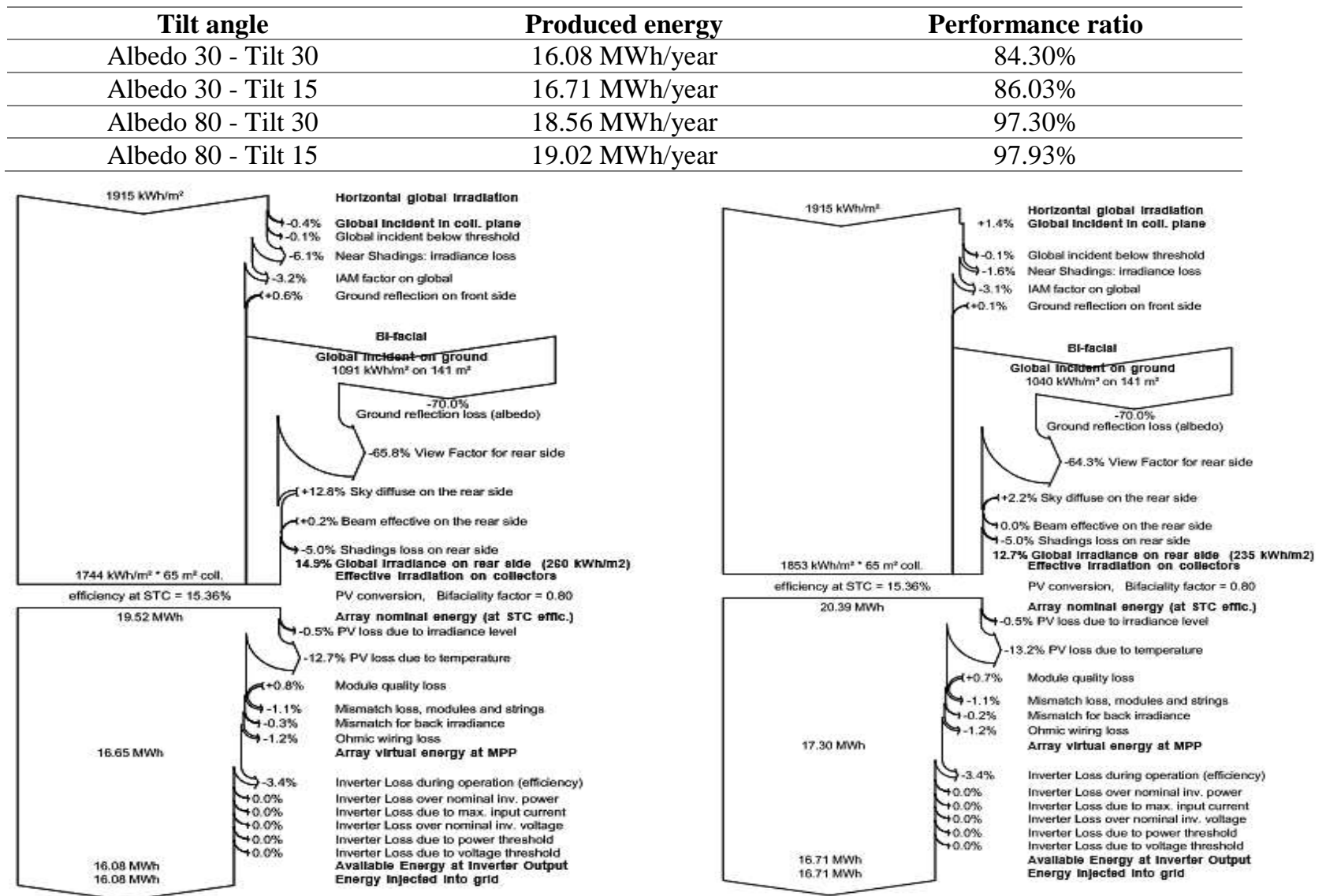

Fig 41. Alb.30 tilt 30 loss diagram

Fig 42. Alb.30 tilt 15 loss diagram 


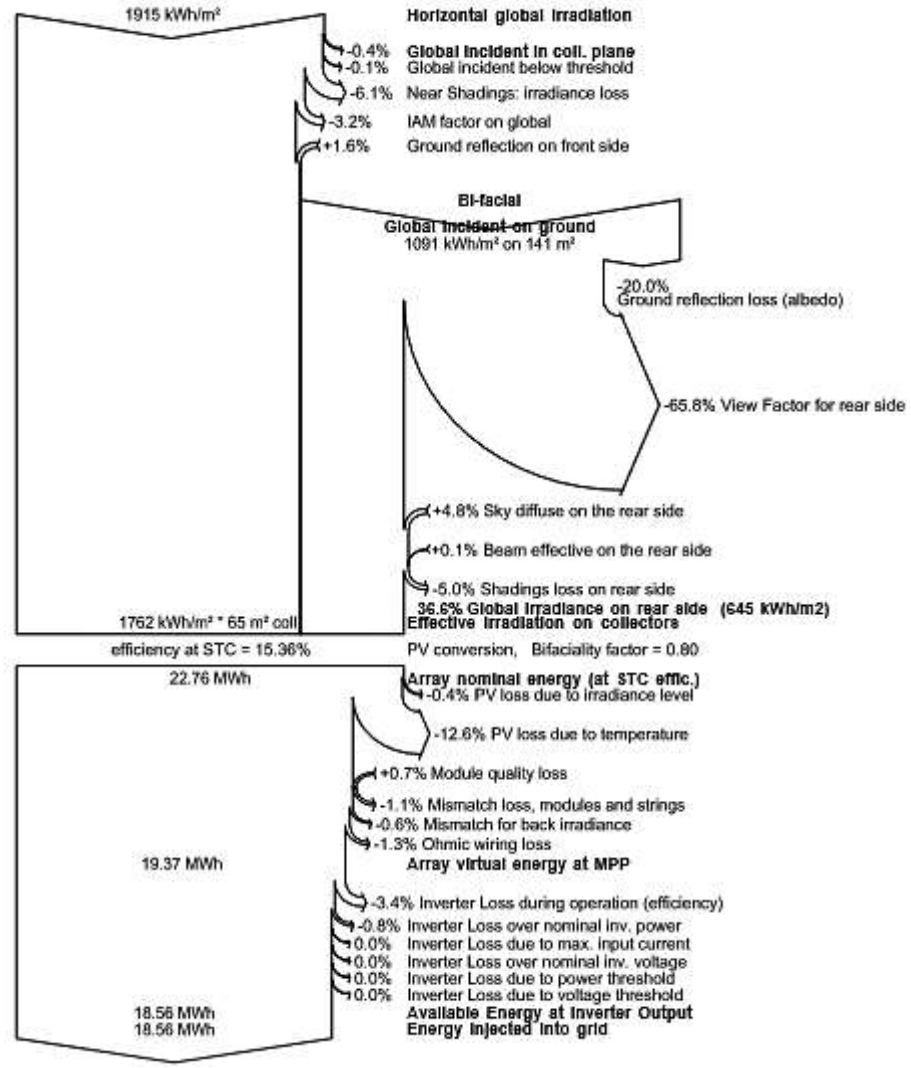

Fig 43. Alb.80 tilt 30 loss diagram

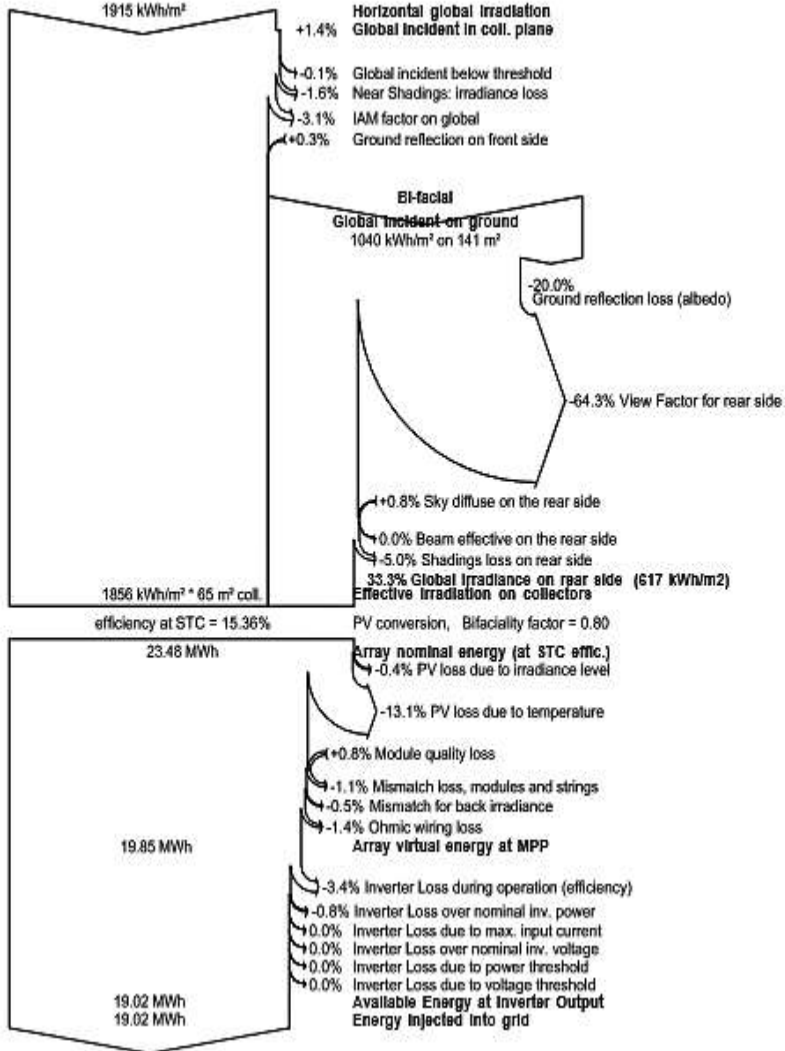

Fig 44. Alb.80 tilt 15 loss diagram

The above Figures of loss diagrams have included temperature losses, Albedo losses, wiring losses, inverter losses and mismatch losses and given an approximate loss diagram for the specific power conditions per year for bi-facial PV system. The use of bifacial PV panels creates significant gain in generation and performance ratio. Therefore, to make a direct comparison, it is created the below table using both bifacial and mono-facial panels obtained generation and performance data.

Table 7. Generation comparison table

\begin{tabular}{|c|c|c|c|c|c|c|}
\hline Mono-facial & $\begin{array}{c}\text { Bi-facial } \\
\text { Albedo } 30\end{array}$ & $\begin{array}{c}\text { Bi-facial } \\
\text { Albedo } 80\end{array}$ & \multicolumn{2}{|c|}{ Generation gain } & \multicolumn{2}{|c|}{$\begin{array}{c}\text { Performance } \\
\text { ratio gain }\end{array}$} \\
\hline 30 degrees tilt & $\begin{array}{c}\text { Tilt } 30 \\
\text { Bifacial PV }\end{array}$ & $\begin{array}{c}\text { Tilt } 30 \\
\text { Bifacial PV }\end{array}$ & Albedo 30 & $\begin{array}{c}\text { Albedo } \\
80\end{array}$ & $\begin{array}{l}\text { Albedo } \\
30\end{array}$ & Albedo 80 \\
\hline $\begin{array}{c}15.08 \mathrm{MWh} / \text { year } \\
79.06 \%\end{array}$ & $\begin{array}{c}16.08 \\
\text { MWh/Year } \\
84.30 \%\end{array}$ & $\begin{array}{c}18.56 \\
\text { MWh/year } \\
97.30 \%\end{array}$ & $6.6 \%$ & $23 \%$ & $5.24 \%$ & $18.24 \%$ \\
\hline 15 degrees tilt & $\begin{array}{c}\text { Tilt } 15 \\
\text { Bifacial PV }\end{array}$ & $\begin{array}{c}\text { Tilt } 15 \\
\text { Bifacial PV }\end{array}$ & Albedo 30 & $\begin{array}{c}\text { Albedo } \\
80\end{array}$ & $\begin{array}{c}\text { Albedo } \\
30\end{array}$ & Albedo 80 \\
\hline $\begin{array}{c}15.37 \mathrm{MWh} / \text { year } \\
79.15 \%\end{array}$ & $\begin{array}{c}16.71 \\
\text { MWh/year } \\
86.03 \%\end{array}$ & $\begin{array}{c}19.02 \\
\text { MWh/year } \\
97.93 \%\end{array}$ & $8.7 \%$ & $23.7 \%$ & $6.88 \%$ & $18.78 \%$ \\
\hline
\end{tabular}

According to the observations, the generation gain in bifacial PV at albedo 30 and tilt angle of 30 is much larger compared to mono-facial PV at tilt angle of $30^{\circ}$. Thus, when the albedo rate increases the generation increases significantly, in such it reaches $23 \%$ of gain in generation at $80 \%$ albedo rate. The generation gain at bifacial PV at albedo 30 and 80 and tilt angle of 15 degrees is greater than tilt angle of 30 degrees. Therefore, the tilt angle in the specific location can be selected as 15 degrees as it gives more generation compared to 30 degrees. Also, increasing the albedo rate, directly influence on the generation of a bifacial panel. According to the findings of researches, the soil contains $25-30 \%$ of albedo rate, and therefore, there is a question of how to create more albedo rate on a ground mounted solar power station. In some applications it was proposed to use dry sand which creates 40 - 
$50 \%$ of albedo rate, unlikely the wet sand is only $20-30 \%$ of albedo rate. The snow contains $70-80 \%$ of albedo rates, but snow also effect on PV panel front side generation decrease since it has shading effect severely. Concrete has an albedo rate of 50-70\%, but it's not feasible to concrete an entire land (as an example 10MW solar park requires 40-50 acres of land) which creates ecological issues. Therefore, creating a higher albedo rate at a large-scale solar power station is a challenge because the sand is the only solution which can give $40 \%$ of albedo rate as a natural alternate. Therefore, under laying aluminum foils can be done as a reflector, thus, it also increases the project cost and vice versa it increase the generation by $23 \%$, Painting and using bricks or any other alternative can be effective thus the practicality of the cleaning process of these are challenging.

Due to these reasons, many large-scale bare land solar power stations does not use bifacial PV panels and only stick to monofacial PV, and as if the Bi-PV panel costs are not significantly higher than the Mono-PV using Bi-PV will effective as it will produce at least 4-5\% gain under albedo rates below 25\%. Mainly these Bi-facial PV can be used in some climate conditions which mentioned in the below table 8 and in roof top rack mounted systems with white roof top painting which has $80 \%$ of albedo rate, and can use as BIPV technology since the tiles inside the building will also act as a medium of reflecting the sun light, also, small scale solar power station such as 1MW PV stations can implement the aluminum foils between sheds on ground as strips or can use any alternative which lies in the boundary of cost factor. Therefore, these simulation data can lead us to that bifacial solar panels are more suitable for higher albedo rated locations, and it can give more generation compared to mono-facial PV panels at 15 degrees tilt and at 80 albedo rates. If the albedo is less than $40 \%$, the ideal condition of PV arrangement will be mono-facial PV panels with 15-20 degrees tilt angle.

Therefore, this paper proposed the below table for PV selection for different environment conditions,

Table 8. Proposed PV selection according to the condition of the location

\begin{tabular}{|c|c|c|c|c|}
\hline Condition of location & Albedo & Suitable PV & Tilt angle & Comments \\
\hline Bare land ground mounted & $0.2-0.3$ & Mono-facial & $15-20$ & N/A \\
\hline $\begin{array}{l}\text { Bare land ground mounted } \\
\text { with single-axis tracking } \\
\text { system }\end{array}$ & $0.2-0.3$ & Mono-facial & $\begin{array}{l}\text { Change with } \\
\text { Sun path }\end{array}$ & N/A \\
\hline $\begin{array}{l}\text { Bare land ground mounted } \\
\text { with dual-axis tracking } \\
\text { system }\end{array}$ & $0.2-0.3$ & Mono-facial & $\begin{array}{l}\text { Change with } \\
\text { Sun path }\end{array}$ & N/A \\
\hline Desert projects & $0.5-0.7$ & Bi-facial & $15-20$ & $\mathrm{~N} / \mathrm{A}$ \\
\hline $\begin{array}{l}\text { Snow climates with glare } \\
\text { sunlight (long winter. Less } \\
\text { summer) }\end{array}$ & $0.6-0.8$ & Bi-facial & $15-20$ & $\begin{array}{l}\text { Cleaning of front surface is must. } \\
\text { Tilt decreased for gain more } \\
\text { generation in Winter. }\end{array}$ \\
\hline $\begin{array}{l}\text { Snow climates with glare } \\
\text { sunlight (Short winter. Long } \\
\text { summer) }\end{array}$ & $0.6-0.8$ & Bi-facial & $20-30$ & $\begin{array}{l}\text { Cleaning of front surface is must. } \\
\text { Tilt increased to less snow deposit } \\
\text { on front surface during short } \\
\text { winter. }\end{array}$ \\
\hline $\begin{array}{l}\text { Snow climates with less } \\
\text { sunlight }\end{array}$ & $0.6-0.8$ & Mono-facial & $20-30$ & Cleaning of front surface is must. \\
\hline Tile roof (clay) PV system & $0.1-0.2$ & Mono-facial & Angle of roof & N/A \\
\hline $\begin{array}{l}\text { Asbestos sheet roof PV } \\
\text { system }\end{array}$ & $0.1-0.2$ & Mono-facial & Angle of roof & N/A \\
\hline $\begin{array}{l}\text { Aluminum sheet roof PV } \\
\text { systems. (light color coated) }\end{array}$ & $0.5-0.8$ & Bi-facial & Angle of roof & N/A \\
\hline $\begin{array}{l}\text { Aluminum sheet roof PV } \\
\text { systems. (dark color coated) }\end{array}$ & $0.2-0.4$ & Mono-facial & Angle of roof & N/A \\
\hline Slab roofs with white coated & $0.5-0.8$ & Bi-facial & $15-30$ & $\begin{array}{l}\text { Mounting structure needed to } \\
\text { obtain the tilt angle }\end{array}$ \\
\hline $\begin{array}{l}\text { Slab roofs with concrete } \\
\text { (Without coating) }\end{array}$ & $0.4-0.6$ & Bi-facial & $15-30$ & $\begin{array}{l}\text { Mounting structure needed to } \\
\text { obtain the tilt angle }\end{array}$ \\
\hline $\begin{array}{l}\text { Street lighting (near tar } \\
\text { roads) }\end{array}$ & $0.1-0.2$ & Mono-facial & $15-20$ & N/A \\
\hline $\begin{array}{l}\text { Street lighting (near concrete } \\
\text { roads) }\end{array}$ & $0.5-0.6$ & Bi-facial & $15-20$ & N/A \\
\hline
\end{tabular}




\section{CONCLUSION}

The paper discussed about the bifacial PV panels vs mono-facial PV panels. The simulations were done for $10 \mathrm{~kW}$ ground mounted solar system and discussed the results at 30 albedo 30 degrees tilt, 30 albedo 15 degrees tilt, 80 albedo 30 degrees tilt and 80 albedo 15 degrees tilt. With respect to the results, it was observed that bifacial solar panels generate more energy per year than mono-facial solar panels, and the most suitable tilt angle is 15 degrees, thus, the generation increasing percentage is higher when the albedo is increasing. Therefore, it can be classified as bifacial PV will perform well under albedo rate of more than $40 \%$ and at tilt angle of 15 degrees, while mono-facial PV will perform well under albedo rate of less than $40 \%$ and at tilt angle of 15 degrees. Therefore, both panels create its unique integrations according to the site conditions which represents in table 8 .

\section{ACKNOWLEDGEMENT}

I wish to record my deep sense of gratitude and profound thanks to my parents for their motivation and support given throughout this research, and thank all the researches who involved in renewable energy studies to make this world more greener and better place.

\section{CERTIFICATION STATEMENT}

I hereby declare that this thesis is my own original work and that, to the best of my knowledge and belief, it reproduces no material previously published or written, nor material that has been accepted for the award of any other degree or diploma, except due acknowledgement has been made in the text.

\section{REFERENCE}

[1] Chris Wedding, "Renewable energy and green building entrepreneurship," Duke University of North Carolina, 2018.

[2] P. Ayala et al., "Bifacial Technology Performance Compared with Three Commercial Monofacial PV Technologies under Outdoor High Irradiance Conditions at the Atacama Desert," in 7th edition of the World Conference on Photovoltaic Energy Conversion (WCPEC-7), 2018, pp. 672-675.

[3] T. Penick and B. Louk, "Photovoltaic power generation," 1998.

[4] M. R. Abdelkader and F. Sharaf, "A comparative Analysis of the Performance of Monocrystalline and Multiycrystalline PV Cells in Semi Arid Climate Conditions : the Case of Jordan,” vol. 4, no. 5, pp. 543-552, 2010.

[5] "Difference Between Monocrystalline and Polycrystalline Solar Panels?," The Renewable Energy Hub, 2017. [Online]. Available: https://www.renewableenergyhub.co.uk/solar-panels/what-is-the-difference-between-monocrystalline-andpolycrystalline-solar-panels.html.

[6] A. Al Tarabsheh, M. Akmal, and M. Ghazal, "Series connected photovoltaic cells-Modelling and analysis," Sustain., vol. 9, no. 3, 2017.

[7] H. Bellia, R. Youcef, and M. Fatima, “A detailed modeling of photovoltaic module using MATLAB," NRIAG J. Astron. Geophys., vol. 3, no. 1, pp. 53-61, 2014.

[8] H. Tian, F. Mancilla-david, K. Ellis, E. Muljadi, and P. Jenkins, "A cell-to-module-to-array detailed model for photovoltaic panels," Sol. Energy, vol. 86, pp. 2695-2706, 2012.

[9] P. Ooshaksaraei, K. Sopian, R. Zulkifli, M. A. Alghoul, and S. H. Zaidi, "Characterization of a bifacial photovoltaic panel integrated with external diffuse and semimirror type reflectors," Int. J. Photoenergy, vol. 2013, 2013.

[10] J. Peura, T. Lina, and L. Fleur, "Evaluation of simulation methods and optimal installation conditions for bifacial PV modules A case study on Swedish PV installations," 2018.

[11] S. M. Kim et al., "A Study of Performance Characterization with Rear Light Source in Conventional Bifacial Solar Cells," 2017, pp. 0-4.

[12] J. P. Singh, S. Guo, I. M. Peters, A. G. Aberle, and T. M. Walsh, "Comparison of Glass/Glass and Glass/Backsheet PV Modules Using Bifacial Silicon Solar Cells,” IEEE J. Photovoltaics, vol. 5, no. 3, pp. 783-791, 2015.

[13] L. Kreinin, A. Karsenty, D. Grobgeld, and N. Eisenberg, "PV systems based on bifacial modules: Performance simulation vs. design factors," in 2017 IEEE 44th Photovoltaic Specialist Conference, PVSC 2017, 2018, pp. 1-4.

[14] Solarworld, "Calculating the Additional Energy Yield of Bifacial Solar Modules," White Paper, 2015. [Online]. 
Available: https://www.solarworld-usa.com/ /media/www/files/white-papers/calculating-additional-energy-yield-throughbifacial-solar-technology-sw9002us.pdf?la=en.

[15] X. Sun, M. R. Khan, C. Deline, and M. A. Alam, "Optimization and performance of bifacial solar modules: A global perspective," Appl. Energy, vol. 212, pp. 1601-1610, 2018.

[16] S. Sciara, S. J. Suk, and G. Ford, "Characterizing Electrical Output of Bifacial Photovoltaic Modules by Altering Reflective Materials,” J. Build. Constr. Plan. Res., vol. 4, no. 4, pp. 41-41, 2016.

[17] B. Zhao, X. Sun, M. R. Khan, and M. A. Alam, "Online Simulation Tools for Global Photovoltaic Performance: Purdue University Meteorological Tool (PUMET) and Bifacial Module Calculator (PUB)," in the 7th World Conference on Photovoltaic Energy Conversion, 2018, pp. 2567-2570.

[18] O. Gunawan, K. F. Tai, and Y. Virgus, "High-sensitivity rotating parallel dipole line hall system for photovoltaic research: Characteristics and application examples in high performance kesterite and perovskite," in 2017 IEEE 44th Photovoltaic Specialist Conference, PVSC 2017, 2018, no. December 2016, pp. 1-4.

[19] A. Asgharzadeh, C. Deline, J. Stein, and F. Toor, "A Comparison Study of the Performance of South / North-facing vs East / West-facing Bifacial Modules under Shading Conditions," in 2018 IEEE 7th World Conference on Photovoltaic Energy Conversion (WCPEC) (A Joint Conference of 45th IEEE PVSC, 28th PVSEC \& 34th EU PVSEC), 2018, pp. 5-9.

[20] C. E. Valdivia et al., "Bifacial Photovoltaic Module Energy Yield Calculation and Analysis," 44th IEEE Photovolt. Spec. Conf., pp. 1-4, 2017.

[21] J. P. Singh, A. G. Aberle, and T. M. Walsh, "Electrical characterization method for bifacial photovoltaic modules," Sol. Energy Mater. Sol. Cells, vol. 127, pp. 136-142, 2014.

[22] M. Sengupta, Y. Xie, A. Lopez, A. Habte, G. Maclaurin, and J. Shelby, "The National Solar Radiation Data Base (NSRDB)," Renew. Sustain. Energy Rev., vol. 89, no. June, pp. 51-60, 2018.

[23] C. H. Whitlock et al., "Release 3 NASA Surface Meteorology and Solar Energy Data Set for Renewable Energy Industry Use,” Proc. Rise Shine, vol. 1, no. 11, pp. 1829-1841, 2000.

[24] C. W. Hansen et al., "Analysis of irradiance models for bifacial PV modules," in 2017 IEEE 44th Photovoltaic Specialist Conference, PVSC 2017, 2018, pp. 1-6.

[25] L. P. Naing and D. Srinivasan, "Estimation of solar power generating capacity," 2010 IEEE 11th Int. Conf. Probabilistic Methods Appl. to Power Syst. PMAPS 2010, pp. 95-100, 2010.

[26] J. Johnson, D. Yoon, and Y. Baghzouz, "Modeling and analysis of a bifacial grid-connected photovoltaic system," IEEE Power Energy Soc. Gen. Meet., pp. 1-6, 2012.

[27] J. Reca-Cardeña and R. López-Luque, "Design Principles of Photovoltaic Irrigation Systems," Adv. Renew. Energies Power Technol., vol. 1, pp. 295-333, 2018.

[28] G. M. Tina, C. Ventura, and S. De Fiore, "Sub-hourly irradiance models on the plane of array for photovoltaic energy forecasting applications," Conf. Rec. IEEE Photovolt. Spec. Conf., pp. 1321-1326, 2012.

[29] J. Ahmed and Z. Salam, “An improved perturb and observe ( P \& O ) maximum power point tracking ( MPPT ) algorithm for higher efficiency," vol. 150, pp. 97-108, 2015.

[30] T. Esram and P. L. Chapman, “Comparison of Photovoltaic Array Maximum Power Point Tracking Techniques,” vol. 22, no. 2, pp. 439-449, 2007.

[31] S. Kundu, N. Gupta, and P. Kumar, "Review of solar photovoltaic maximum power point tracking techniques," India Int. Conf. Power Electron. IICPE, vol. 2016-Novem, pp. 1-6, 2017. 